\title{
State Capacity and the Environmental Investment Gap in Authoritarian States
}

\section{Hugh Ward, Xun Cao, and Bumba Mukherjee}

\begin{abstract}
November 6, 2012
Abstract: We construct an n-period, constrained optimization model where the authoritarian ruler maximizes expected rents subject to budget constraint of available surplus. We show that the larger state capacity is in the previous period, the worse environmental quality will be in the next period: while both infrastructural investment and environmental protection increase with state capacity, the former increases at a faster rate which enlarges the gap between the two --- the environmental investment gap. Given infrastructural public goods typically damage the environment, the larger this gap is the worse the environmental quality would be. This follows from rulers' optimizing logic of equating marginal returns once we assume the declining marginal productivity of factors of production of surplus. We model three types of air and water pollutants in autocracies as a function of state capacity and other relevant variables. State capacity is associated with higher levels of all three types of pollutants.
\end{abstract}




\section{Introduction}

In 1980, 55.9 per cent of the world population lived under some form of authoritarian rule. By 2000, after waves of democratization, this number was still as high as 42.1 per cent. ${ }^{1}$ How does authoritarian politics affect countries' environmental performances? This is an important and yet unanswered question for students of political science. Previous research on the environmental impact of political institutions often focuses on the democracy-non-democracy divide (Congleton 1992, Li and Reuveny 2006). Some have argued that liberal-democracy could be detrimental to environmental protection (Dryzek 1987, Midlarsky 1998). More recent research seems to suggest that democracies are often associated with more stringent environmental regulations and sometimes better environmental outcomes (Barret and Graddy 2000; Esty and Porter 2005; Bernauer and Koubi 2008). However, given the fact that different kinds of authoritarianism differ from each other as much as they differ from democracy (Geddes 1999), we need to further investigate the dynamics of environmental politics in the authoritarian world.

Unfortunately, we know little about environmental politics in authoritarian systems. This is understandable because the types of political institutions often studied by students of social sciences are usually missing from authoritarian politics. For instance, political economy models of electoral rules (proportional representation vs. majoritarian) and democratic political regimes (presidential vs. parliamentary system) have informed the recent environmental politics literature that connects these formal institutions to environmental policy outputs and outcomes (Fredriksson and Millimet 2004; Fredriksson and Wollscheid 2007; Broz and Maliniak 2011). However, these models are based on democratic politics and

\footnotetext{
${ }^{1}$ These mainly comprise single-party, military, personalistic, monarchical, and their hybrid regimes. Percentages are calculated by the authors, using Wright 2008's extension of Geddes' data of authoritarian regime types (Geddes 1999). Note these are likely to underestimate the number of people living under authoritarian rules, because there are non-democratic regimes that are not yet classified by the data.
} 
therefore provide little help when it comes to understand the dynamics of environmental politics in non-democratic systems.

Our understanding of politics in authoritarian systems is also much more limited than that of democratic systems. Recent literature on authoritarianism has focused on the classification of authoritarian regimes (Geddes 1999, Lai and Slater 2006, Cheibub and Gandhi 2004, Cheibub, Gandhi and Vreeland 2009) and the links between these regime types and various phenomena such as regime survival (Geddes 2003), democratic transition and consolidation (Svolic 2008), economic development (Gandhi 2008, Wright 2008), and initiation of conflicts (Pickering and Kisangani 2010, Weeks 2011). Though there is an abundant case study literature on environmental regulations and outcomes in authoritarian systems (Mumme, Bath, and Assetto 1988; Pryde 1991; Economy 2004; Doyle and Simpson 2006), unfortunately little systematic theoretical work has been carried out, and we lack systematic studies of how outcomes are related to variance among authoritarian systems.

In this paper, we present a model of environmental politics in an authoritarian system starting with the basic assumption of a rent-maximizing authoritarian ruler. We construct an n-period, constrained optimization model where the authoritarian ruler maximizes expected rents subject to the budget constraint of the surplus that he has available in the short-term. We show that it is typically the case that the larger state capacity is at time $t$, the worse environmental quality at time $\mathrm{t}+1$ : strong state capacity increases both infrastructural investment and environmental protection, but as long as the productivity of infrastructural investment relative to its price is greater than that of environmental protection, the former would increase at a faster rate, which enlarges the gap between the two. We call this the environmental investment gap. Based on the assumption that infrastructural public goods are typically provided in a way that damages the environment, we argue that the bigger the gap is the worse environmental quality will be. This result follows from rulers' optimizing logic of 
equating marginal returns once we assume the declining marginal productivity of factors of production of surplus.

We test our theory by modeling three types of major air and water pollutants, sulphur dioxide $\left(\mathrm{SO}_{2}\right)$, carbon dioxide $(\mathrm{CO})$, and biological oxygen demand (BOD) in authoritarian states as a function of the capacity of the state and a battery of relevant variables, for 19802003. The results strongly support our theory. Higher state capacity is associated with higher levels of all three types of pollutants. The rest of the paper describes our theoretical model, presents data and variable operationalizations, and finally discuss the empirical findings and direction of future research.

\section{A Model of Environmental Politics in Authoritarian States}

Rulers can obtain surplus either by extracting part of the national income stream or by selling or running down parts of the national stock of capital that they control. In attempting to maximize the rents rulers in authoritarian regimes enjoy through monopoly of state power, they face a short-term long-term tradeoff. The surplus the authoritarian ruler (hereafter "ruler") has extracted at time t might be enjoyed as rent at that time. On the other hand the ruler could invest it so as to enjoy higher future rents at t' $>t$. First the ruler can invest in capital which increases the size of future national income. Second he can invest in additional state capacity, which will allow him to extract a greater surplus in the future. Third he may make investments in legitimacy, which increases the probability that he will survive in office until the next time period. We discuss each of these forms of investment in turn.

Part of surplus is extracted from national income. National income is produced by labor, capital, infrastructural public goods and environmental public goods. We assume a fixed supply of labor and capital in the hands of private owners. Positive investment by the ruler in infrastructural public goods such as roads and energy systems should increase future national income. On the other hand a ruler might run down the stock of infrastructural capital to 
increase the rent he enjoys at $t$, with negative consequences for future national income. Infrastructural capital depreciates. One way of running it down is simply not to maintain it, for example, not to make road repairs. Environmental public goods are also important to production, and rulers can invest in future income by protecting them, through implementing environmental regulations. Again a ruler can disinvest, pushing up the surplus he extracts in the short term at the cost of lower future income. For example he may exploit national forests unsustainably, selling off the timber or allowing his cronies to do so, which we treat as an erosion of environmental protection.

We assume that the environmental quality at $\mathrm{t}$ is a function of the difference between the levels of infrastructural public goods and environmental protection in that period - the environmental investment gap. This is based on the assumption that infrastructural public goods are typically provided in a way that damages the environment. Of course this is not always true, for instance a more efficient electricity distribution system enhances the environment. We simply bypass this issue by definition by categorizing such an investment as an environmental investment. Rulers control state capacity. If they invest in extra state capacity at t, other things equal they should be able to enjoy higher future rents (Besley and Persson 2010). However they may also disinvest. For instance they could run down the size of the military and sell the assets freed up. Again this would allow them to enjoy higher rents in the short term.

In addition to controlling state capacity, authoritarian rulers - similar to their counterparts in democratic states - are interested in survival in office. Extant studies in fact suggest that since democratic leaders rely on a larger winning coalition for political survival compared to authoritarian rulers, incumbents in democracies tend to supply public rather than private goods to garner political support from members in the larger winning coalitions (Lake and Baum 2001; Bueno de Mesquita et al 2003). This is because public goods by definition 
are supplied broadly, and it is relatively cheaper and more efficient for democratic leaders to provide such goods to their larger support base to prolong their survival in office (Bueno de Mesquita et al 2003). Unlike democratic leaders, rulers in authoritarian regimes often depend on support from a smaller winning coalition to retain power. Relying on support from a smaller winning coalition makes it more feasible and efficient for authoritarian rulers to provide private good transfers to narrow group of supporters to maximize their likelihood of political survival (Bueno de Mesquita et al 2003). Since our model analyzes environmental politics in an authoritarian regime, we build on the studies mentioned above and assume that the (i) authoritarian ruler focuses on supplying private good transfers to his small core group of supporters and (ii) the probability a ruler survives until the next time period increases with the amount he provides in private transfers to his supporters. Of course such private good transfers cannot take negative values, because income is extracted from the generality of citizens, not the selectorate. We also assume that public good provision, whether infrastructural or environmental, does not increase the chances of survival. Public goods are available both to a larger segment of the population in the selectorate and to those in the winning coalition, so they provide no particular motive for members in the smaller winning coalition to support the ruler. ${ }^{2}$

The ruler plans investment over a finite number of periods $0 \leq t \leq T$, where $T \geq 2$ is the maximum period he believes he could possible stay in office. T could be set by institutional rules, such as those governing succession in the Chinese Communist Party, or by beliefs about biological longevity. The ruler does not necessarily expect to survive this long in office, though. Denote the subjective probability that he will survive until time $t$ by $\Pi_{t}$, with $\Pi_{0}=1$ since the ruler is in office at the time of plan formulation. Let $s_{t}$ be the level of private good

\footnotetext{
${ }^{2}$ If private goods only provide services that can be enjoyed if adequate levels of public goods are also available this would not generally be the case. For instance a member of the selectorate could only enjoy privileged access to a private car to the extent to which uncrowded roads exist to drive on. We do not attempt to model this aspect here.
} 
transfers to members of the selectorate at time t. Notice that a constraint (denoted as "C") on the ruler is such that

$$
\mathrm{C} 1: \mathrm{s}_{\mathrm{t}} \geq 0
$$

since we assume surplus is not extracted from the selectorate. The probability that the ruler survives from period $\mathrm{t}$ to period $\mathrm{t}+1,0 \leq \mathrm{t}<\mathrm{T}$ will be denoted by $\pi_{\mathrm{t}}, 0<\pi_{\mathrm{t}}<1$, assumed to be a strictly increasing function of $\mathrm{s}_{\mathrm{t}}{ }^{3}$ Further we assume $\Pi_{\mathrm{t}+1}=\pi_{\mathrm{t}} \Pi_{\mathrm{t}} \quad 0 \leq \mathrm{t}<\mathrm{T}$. Notice this is to treat survival between periods as a sequence of stochastically independent events.

Let the levels of infrastructural public goods, environmental protection, and state capacity at time $t$ be $I_{t}, E_{t}$ and $C_{t}$, respectively. Let investments at time $t$ in these things be $i_{t}$, $e_{t}$ and $c_{t}$ respectively. Recalling that the ruler can disinvest up to the point that all these factors are used up, the ruler also faces constraints:

$\mathrm{C} 2: \quad \mathrm{i}_{\mathrm{t}} \geq-\mathrm{I}_{\mathrm{t}}$

C3: $e_{t} \geq-E_{t}$

C4: $\quad c_{t} \geq-C_{t}$

Total levels of - the three factors accumulate through investment from $t=0$. Thus, for instance, for $\mathrm{t}>0$

$$
\mathrm{I}_{\mathrm{t}}=\mathrm{I}_{\mathrm{o}}+\sum_{\mathrm{t}^{\prime}=0}^{\mathrm{t}-1} \mathrm{i}_{\mathrm{t}^{\prime}} .
$$

Let $\mathrm{Y}_{\mathrm{t}}$ be the surplus that the ruler has extracted from national income at time t. Then a further constraint is that

C5: $Y_{t} \geq s_{t}+p_{I} i_{t}+p_{E} e_{t}+p_{C} c_{t}$

\footnotetext{
${ }^{3}$ Transferring private goods to his core group of supporters helps an autocrat to reward such members in the narrow winning coalition for their loyalty (Bueno de Mesquita et al 2003). This reduces the incentives for such supporters to overthrow their autocratic leader which in turn serves to increase the leader's probability of survival in office (Bueno de Mesquita et al 2003). This explains why we assume that $\pi_{\mathrm{t}}$ is a strictly increasing function of $\mathrm{s}_{\mathrm{t}}$.
} 
where the price of private goods is 1 , so they are the numeraire, and $\mathrm{p}_{\mathrm{I}}, \mathrm{p}_{\mathrm{E}}$ and $\mathrm{p}_{\mathrm{C}}$ are the prices of infrastructural public goods, environmental protection and state capacity, respectively. Notice that if the ruler disinvests in infrastructure, say, this constraint becomes easier to satisfy. Implicitly it allows both for extraction from income and running down capital. This is an important technical feature of our model as it formally incorporates the dynamic from the literature of dictatorships that authoritarian rulers (unlike democratic leaders) are more likely to engage in "predation" in office that leads to income extraction and a decline in capital (e.g. Grossman and Noh 1990; McGuire and Olson 1996).

Take $\mathrm{Y}_{\mathrm{o}}$ as given. For $0<\mathrm{t} \leq \mathrm{T}$ we assume $\mathrm{Y}_{\mathrm{t}}$ depends on a Cobb-Douglas 'surplus production function':

$$
\mathrm{Y}_{\mathrm{t}}\left(\mathrm{I}_{\mathrm{t}}, \mathrm{E}_{\mathrm{t}}, \mathrm{C}_{\mathrm{t}}\right)=\mathrm{A} \mathrm{I}_{\mathrm{t}}^{\alpha} \mathrm{E}_{\mathrm{t}}^{\beta} \mathrm{C}_{\mathrm{t}}^{\gamma}
$$

where $\mathrm{A}>0$ and $0<\alpha, \beta, \gamma<1$. Notice that $\alpha, \beta$, and $\gamma$ measure the productivity for the ruler's surplus of, respectively, infrastructure, environmental protection and state capacity. Also notice that we assume that investments only affect surplus extracted in subsequent time periods.

The ruler's rent in period $t$ is $R_{t}=Y_{t}-\left(s_{t}+p_{I} i_{t}+p_{E} e_{t}+p_{C} c_{t}\right)$. Subject to constraints $\mathrm{C} 1$ through $\mathrm{C} 5$ above and initial investment stocks $\mathrm{I}_{0}, \mathrm{E}_{0}$, and $\mathrm{C}_{0}$, with dicount parameter $\varphi, 0$ $<\varphi<1$, he seeks to maximize discounted, expected rents over his maximum period in office

$$
\mathrm{R}_{\Sigma}=\sum_{\mathrm{t}=0}^{\mathrm{T}} \varphi^{\mathrm{t}} \Pi_{\mathrm{t}} \mathrm{R}_{\mathrm{t}}
$$

The fact that the authoritarian ruler in our model seeks to maximize his discounted rents is drawn from models of dictatorships which assume that "dictators want to maximize their rent" (Gandhi and Przeworski 2006:2; also see Wintrobe 1990; Grossman and Noh 1990). The assumption of a rent-maximizing authoritarian ruler is distinct from models of trade or fiscal policymaking in democracies which typically assume that democratic incumbents maximize a weighted objective function in which the incumbent weighs social welfare and 
contributions from interest groups (Grossman and Helpman 1994; Battaglini and Coate 2008). The distinction alluded to above is vital considering that our model focuses on authoritarian regimes. It also has important substantive implications that are explored below.

At this stage, it is easily seen from the expression for $\mathrm{R}_{\Sigma}$ that only an extremely futureorientated ruler would take no rents at time t, investing his entire surplus for that round. To rule out this empirically unlikely occurrence we assume $\mathrm{C} 5$ is slack. We also assume constraints $\mathrm{C} 1-\mathrm{C} 4$ are slack on the grounds that it is probably impractical for rulers to completely disinvest during their lifetimes. So we avoid discussion of corner solutions to the program, focusing on the properties of the internal solution.

Environmental quality at $\mathrm{t}+1,0<\mathrm{t}+1<\mathrm{T}$, is assumed to be a function of the environmental investment deficit $D_{t+1}=\left(I_{t}+i_{t}\right)-\left(E_{t}+e_{t}\right)$, recalling that total factor levels at time $t+1$ are the sum of the lagged value at $t$ plus additional investments at $t$. The environmental quality function, $\varepsilon_{\mathrm{t}+1}\left(\mathrm{D}_{\mathrm{t}+1}\right)$, is such that $\delta \varepsilon_{\mathrm{t}+1} / \delta \mathrm{D}_{\mathrm{t}+1}<0$. In the online appendix we show that ${ }^{4}$

$$
D_{t+1}=\left(\left(\alpha p_{E}-\beta p_{I}\right)\left(k_{t}+p_{I} I_{t}+p_{E} E_{t}+p_{C} C_{t}\right)\right) /\left(p_{I} p_{E}(\alpha+\beta+\gamma)\right)
$$

Where $\mathrm{k}_{\mathrm{t}}$ is the amount invested, excluding what is spent on private goods going to the selectorate. Then $D_{t}$ increases with $I_{t}, E_{t}$ and $C_{t}$ so long as $\alpha p_{E}>\beta p_{I}$ or $\alpha / p_{I}>\beta / p_{E}$, which is to say that the productivity of surplus of infrastructural investment relative to its price is greater than that of environmental protection. ${ }^{5}$

Because we can operationally measure state capacity, we focus discussion on this term. The larger the stock of state capacity $\mathrm{C}_{\mathrm{t}}$, the lower the level of environmental quality at time $\mathrm{t}+1$ so long as the productivity of infrastructural investment relative to its price is greater than the productivity of environmental investment relative to its price. If we assume additionally

\footnotetext{
${ }^{4}$ We solve for and formally characterize $\mathrm{D}_{\mathrm{t}+1}$ in the "proof of Lemma 1 " in the appendix. ${ }^{5}$ We show in the "proof of Proposition 1" in the appendix that $D_{t}$ strictly increases with respect to $\mathrm{C}_{\mathrm{t}}$
} 
that at relatively low levels of development infrastructural investment is typically more productive of ruler surplus than environmental investment, ${ }^{6}$ then:

H1: Other things equal, the higher the level of state capacity the lower the level of environmental quality in authoritarian systems at relatively low levels of development.

The mechanism behind this result is as follows. Constraints are assumed slack so at the optimum the ruler equates the marginal productivity of surplus with respect to factors across his possible investments. Moreover the marginal productivity of factors is declining, because of the 'Cobb-Douglas' production function. The larger $\mathrm{C}_{\mathrm{t}}$ is the lower is marginal productivity of state capacity before investment/disinvestment. So the larger $C_{t}$ is the further investment in infrastructure and the environment are pushed in equilibrium. ${ }^{7}$ A greater stock of state capacity increases both infrastructural investment and environmental protection, but the investment gap grows if infrastructural investment grows more in relative terms, which it will if it is relatively more productive of surplus. ${ }^{8}$

Stated in more simple language, one key implication that emerges from the model's technical mechanism summarized above is that greater state capacity will rationally induce autocrats to increase investment in infrastructure and the environment. To see why, first note that increasing investment in infrastructure reduces intermediate input costs that raises economic output (World Bank 2012). Higher output that results from infrastructure

\footnotetext{
${ }^{6}$ Research by development economists and the World Bank suggests that infrastructural investment in developing states positively affects the economy's output and productivity through a variety of channels (Esfahani and Ramirez 2003;World Bank 2012). Infrastructure investment reduces the costs of intermediate inputs used for production. It also directly enhances productivity, increases private capital formation (by raising expected returns on private investments as the marginal productivity of inputs increases or transaction costs decline) and facilitates the exploitation of agglomeration economies. It is thus plausible - as we presume - that the productivity of surplus of infrastructural investment relative to its price not only grows sharply in autocracies (since autocracies only exist in the developing world) but is also greater than that of environmental protection.

${ }^{7}$ We formally substantiate this claim in the appendix.

${ }^{8}$ However there may be atypical cases of highly polluted systems where it is more productive of surplus at the margin for a ruler to invest in environmental protection (i.e. $\alpha / p_{I}<\beta / p_{E}$ ). We return to this possibility in the conclusion.
} 
investment not only generates more capital but also provides an opportunity for authoritarian rulers to extract more rent from the larger pool of capital realized from higher output. Because the authoritarian ruler in our model seeks to maximize his discounted rents, he thus has incentives to raise output via investment in infrastructure as this produces more rent for the ruler. This argument is similar to Gandhi and Przeworski's (2006: 2) claim that dictators "always seek to maximize total output: even if they are forced to share rents with some groups of the potential opposition, their rents are higher when total output is higher". Note, however, that the authoritarian ruler's incentive to extract more rent by raising output via infrastructural investment is a necessary but not sufficient condition for increasing investment in infrastructure.

Rather our model predicts that greater state capacity provides the ruler with the necessary economic ability required to invest more in infrastructure which raises output and consequently leads to higher realized rent for the ruler. Furthermore, since the authoritarian ruler is less politically constrained than democratic leaders, he has sufficient political room for maneuver to employ greater state capacity to generate more rent by (as explicated above) raising output via increasing infrastructure investment. Our model also suggests that greater state capacity provides the ruler with more leverage to invest in the environment. Investing in the environment curtails production bottle-necks by reducing negative externalities and this in turn further boosts output which generates more rent for the authoritarian ruler. Although greater state capacity has a positive effect on infrastructural and environmental investment, we find in our model that the environmental investment gap grows if - as discussed above - infrastructural investment grows more than environmental investment; this occurs when the former is relatively more productive of surplus.

In contrast to authoritarian rulers, democratic incumbents on average place more weight on maximizing social welfare rather than rent (Lake and Baum 2001). They are also more 
institutionally constrained by de facto opposition parties in the legislature whose policy preferences may diverge from the incumbents "ideal-point" and whose interests are unlikely to be consistent with maximizing the incumbent's discounted rents. Since democratic leaders place more weight on increasing social welfare rather than rent-extraction, their incentives to use state capacity to generate more rent by raising output are low compared to authoritarian rulers. Higher institutional constraints faced by democratic leaders also make it substantially more difficult for these leaders to employ state capacity to implement policies - e.g. increasing investment in infrastructure and the environment - that they may prefer as opposition parties can credibly veto such policies. Thus unlike authoritarian regimes, we anticipate that higher state capacity is likely to have a negligible and insignificant (in the statistical sense) impact on environmental investment gap in democracies.

\section{Data and Measurement}

Air and Water Pollution: In order to test the impact of the capacity of the state on the environment, we choose to focus on three major types of air and water pollution with available data covering enough countries and years: Sulphur dioxide $\left(\mathrm{SO}_{2}\right)$, carbon dioxide $\left(\mathrm{CO}_{2}\right)$, and bio-chemical oxygen demand (BOD). ${ }^{9}$ Sulphur dioxide is a serious air pollutant, implicated in ground-level smog and haze, particularly in urban areas. It is associated with damage to human health and it reduces agricultural productivity and. It often results in aciddeposition, which damages vulnerable aquatic and forest ecosystems and buildings (Hill 2004). Around two-thirds of emissions result from fossil fuel-burning electricity generation. In developed countries the trend has been towards reductions in emissions due to changes to

\footnotetext{
${ }^{9}$ We choose not to model environmental policies and regulations because recent studies have shown that even with stringent laws on the books, governments can and often do cut enforcement budgets, reduce penalties for enforcement violations, and adopt administrative policies, all of which undermine enforcement effectiveness of policies (Cao and Prakash 2012). And we expect that the gap between law on paper and environmental outcomes is likely to be large especially for developing countries.
} 
less sulphurous fossil fuels, deindustrialization, domestic legislation such as the US Clean Air Act of 1973, pollution control technologies encouraged by regional arrangements like the 1988 EU Large Combustion Plant Directive, and the international Convention of Long-Range Transboundary Air Pollution. However, emissions are still increasing in rapidly growing developing countries many of which are authoritarian regimes. We measure sulphur dioxide emissions in kilograms per-capita per year. ${ }^{10}$ We take the logarithm of all three dependent variables to rescale extreme values and approximate a normal distribution.

Carbon dioxide is the most significant anthropogenic forcing factor for climate change. ${ }^{11}$ Hence it is also implicated in an enormous range of problems, including potential food scarcity, health, development, security, and loss of biodiversity. It has been under intense discussion since the late 1980s, primarily under the umbrella of the 1992 Framework Convention on Climate Change. Despite the entering into force of the 1997 Kyoto Protocol in 2005, regional action such as the EU Emissions Trading Scheme, and action at state and local scales, policy has had little impact to date. We use $\mathrm{CO}_{2}$ emissions in metric tonnes per capita from the World Bank's Development Indicators. Emissions have fallen in some countries since the 1980s partly as a consequence of shifts in fuel or closing polluting heavy industry. Bio-chemical oxygen demand (BOD) is an important indicator of water pollution and it measures the amount of oxygen required to decompose a given amount of organic pollutant. Organic matter entering rivers and lakes is decomposed by micro-organisms, and their activity depletes the oxygen dissolved in the water. Beside natural flows of organic matter, there are flows from sewage discharge and from industrial processes like paper production. These flows push up bio-chemical oxygen demand, and in the extreme can lead to the water becoming hypoxic and unable to support life (Hill 2004). The measure we draw from World Bank Development Indicators is based on the standard test for this form of environmental

\footnotetext{
${ }^{10}$ See Stern 2005.

${ }^{11}$ Other pollutants have greater forcing potential per-unit, though.
} 
stress, bio-chemical oxygen demand in kilograms per-day, per-capita. This is, then, a measure of anthropogenic organic pollution of waterways. ${ }^{12}$

State Capacity: In order to capture the concept of the capacity of the state, we use two different fiscal measures of state capacity from Arbetman-Rabinowitz and Johnson (2007): the state's tax revenue as a ratio of GDP (Tax ratio) and relative political capacity $(R P C) .{ }^{13}$ Tax ratio measures states' ability to extract resources from individuals and groups in society; it is the conventional gauge of the state's extractive capacity (Campbell 1993; Cheibub, 1998; Centeno, 2002; Thies, 2005 and 2010). Relative political capacity (RPC) further conceptualizes state's relative political capacity as the "the ability of a government to extract resources from a population given their level of economic development" (ArbetmanRabinowitz and Johnson 2007, 2). It is a measure of the strength of the state compared to other states with similar levels of development and resource endowments.

RPC is an index that compares the actual level of tax revenue extraction to a predicted level of extraction. Predicted revenues are estimated as a function of per capita income, the share of agriculture in the economy, the share of mining in the economy, and major oil production. A state that scores 1 on the RPC indicator is extracting exactly as one would expect compared to other states with similar conditions, while those that score higher than 1 are extracting more than expected and those that score lower than 1 are extracting less than expected. The relative political capacity score was originally developed by Organski and

\footnotetext{
${ }^{12}$ Inorganic pollution, for instance, that due to run-off of nitrates and phosphates from agriculture, may also deplete oxygen by generating algal blooms, but BOD is not a direct measure of this, and we know of no internationally comparable data.

${ }^{13}$ Other measures of state capacity are also often used in the literature, such as government consumption and government total revenue. However, we think these alternative measures are problematic for our purposes. Government consumption is a measure of the amount of a society's resources consumed by government. It measures expenditures, rather than revenue gathering activity. Total government revenue is a measure of the government's income that includes both tax and non-tax revenue. It is not typically seen as the best measure of revenue extraction, since it contains non-tax revenue.
} 
Kugler (1980) as a proxy for states' relative ability to wage war, and has proven useful in conflict studies (Ties 2010) and in recent work on carbon emissions (Sprinz et al. 2009). Authoritarian Regime Types: Our theoretical model focuses the effect of state capacity in authoritarian states. We adopt a parsimonious approach in which the ruler's only incentive is to maximize the expected surplus that she can extract from the society. However, other factors might also systematically affect ruler's choice between infrastructures and environmental public goods. Geddes has shown that different authoritarian states constitute different political "games" for rulers and their key supporters by providing them with different incentive structures (Geddes 1999): for instance, in a single-party regime, factions within the party often play a stag hunt game, so it is better for them to stay in rather than leaving the party, which accounts for the resilience of this type of regime. It is plausible that systematic differences between these authoritarian regime types affect ruler's policy choices, including those affecting the environment. For instance, leaders in regimes that tend to last longer (e.g., single-party regimes) might have a longer time horizon and therefore are more likely to care about the environment. In addition to time horizons (which are hard to measure empirically), regime types might proxy other systematic differences between authoritarian systems such as the size of distributional coalitions (Peceny and Butler 2004; Wright 2009; Chang and Golden 2010; Pickering and Kisangani 2010). ${ }^{14}$ It is therefore important for us to control for authoritarian regime types in the empirical analysis. We follow Geddes' typology of authoritarian regimes and use an extended version of the data from Wright $2008 .{ }^{15}$ There

\footnotetext{
${ }^{14}$ Rulers lacking easily available revenue such as foreign aid or rents from natural resources are often under considerable pressure when they need to provide payoffs to members of large distributional coalitions. They are more likely to over-exploit natural resources and the environment in order to survive.

${ }^{15}$ Note that Geddes originally offered a straightforward classification of regimes as military, personalist, and single-party: in military regimes, a group of officers decides who will rule and influence policy; in single party regimes, one party dominates access to political office and controls policy; in personalist regimes, access to office and the fruits of office depends on the discretion of an individual leader. The original data spanned from 1950 to 2000, but did
} 
are some hybrid regimes coded in the data (e.g., military-personalist and single-partymilitary). These hybrid regimes might exhibit characteristics of two or more of the two pure regime types. Therefore, we choose to focus on the four pure types of authoritarian regime types to capture the authoritarian regime type effects. ${ }^{16}$

Socialist/Communist Legacies: Communist regimes have often adopted a progressivist perspective based on Marx and Engels' idea that the road to communism lies through the development of the forces of production. In practice, communist regimes tended to develop forces of production by investment in heavy industry, mining, and massive irrigation and hydro-electric projects. While the case-study literature on communist regimes finds it difficult to disentangle this ideology from other variables such as relative under-development, it is frequently held to be one factor lying behind such problems as heavy air and water pollution in the Soviet Union (Oldfield 2005, 21-42). Beside ideology, it is commonly held that Soviet central planning was wasteful of resources, because inputs and use of pollution sinks came un-priced to enterprises bent on plan fulfillment, and led to under-investment in cleaner plant, because of short-term pressures to maximize production (Ericson 1991). Another reason to control for communist legacies is that many single-party regimes are associated with communist/socialist experience; we need to tease out the effect of communist legacies in order to make it a convincing case that it is the size of the constituencies (and state

not include monarchies and only included data on regimes that endured more than three years. Wright 2008 updated the Geddes data to include monarchies, such as Saudi Arabia, Morocco, and Kuwait.

${ }^{16}$ Between 1946 and 2003, roughly $22 \%$ of the total observations are coded as hybrid regimes; so we are not losing too many observations. More importantly, our key finding concerning the positive relationship between state capacity and pollution is robust to the inclusion of these hybrid regimes. 
capacity) that impact the environment. ${ }^{17}$ We therefore add a dummy variable indicating whether a country has ever been a communist or socialist regime. ${ }^{18}$

Further Control Variables: We include both GDP per capita (in purchasing power parity) and its squared term in the model to capture the possibility that there is a curvilinear relationship between wealth and environmental protection. This is to test the Environmental Kuznets Curve argument that there is a $\mathrm{U}$ shape relationship between economic development and environmental protection. Moreover, rapid economic growth may generate forms of environmental damage that are hard to cope with in the short-term. We therefore include GDP growth rate. Our model also includes the share of industrial production in GDP (Industry) because industry is often associated with higher levels of pollution than the service and agricultural sectors. We further control for Fuel exports (as a percentage of merchandise exports) given the negative environmental impacts associated with the exploration, drilling, and extraction of fossil fuels (O’Rourke and Connolly 2003).

We include two demographic variables, Population density (population divided by land area) and Urban population (as a share of total population) to control for demographic influences on pollution levels. Countries with high population density might prioritize development at the expense of environmental protection. Large urban population might also increase the environmental burden on the country; but urban population is also likely to be associated with environmental activism and protection. ${ }^{19}$ We controls for Trade openness (the sum of imports and exports as a percentage of GDP) which has been used extensively in the

\footnotetext{
${ }^{17}$ The correlation between communist legacies and single-party regime is indeed 0.45 in our data.

${ }^{18}$ Countries that have been coded 1 for this dummy variable and potentially enter the empirically analysis after deletion of missing data are Albania, Bulgaria, China, Hungary, Mongolia, Poland, Laos, Mozambique, Angola, Cambodia, Vietnam, Somalia, and Afghanistan.

${ }^{19}$ Data on GDP per capita, GDP growth rate, industrial production, oil exports, population density, and urban population are from the World Development Indicators (World Bank 2008).
} 
trade-environment literature to capture the effect of overall trade openness (de Soysa and Neumayer 2005).

Finally, any account of environmental politics will be incomplete without taking into account societal demands for more/less environmental protection. We, like many previous studies, have implicitly assumed that the public demands a cleaner environment. However, how strong that demand is and to what extent people are willing to give up part of their income for environmental protection is largely unknown, especially for many authoritarian states. It is therefore important to control for relative demand for environmental public goods. However, data on public opinion concerning environmental demand are limited, especially for developing countries (Kvaløy, Henning Finseraas and Listhaug 2012). ${ }^{20}$ Income is probably the best available proxy. Indeed, this is another justification for including GDP per capita and its square term.

Insert Table 1 about here.

Another important societal demand is associated with the energy intensive sectors and the common assumption is that these sectors prefer less stringent environmental regulations. For example, Ward and Cao 2012 have shown that in the OECD context, the larger the size of these sectors, the lower the level of environmental taxation in a country. Energy intensive sectors can be identified, for instance by reference to those included in the EU's CO2 emissions trading scheme such as electricity generation, cement production, and glass making. In principle, the power of such sectors could be measured by their contribution to GDP, but available breakdowns of GDP are not fine enough to make this practicable. Things are more straightforward on the production side. We use the World Development Indicators (WDI)

\footnotetext{
${ }^{20}$ The World Values Survey and European Value Survey are the best sources for public opinion data on environmental demand in terms of country and year coverage. These surveys have a number of questions relating to the environment, depending on wave and country concerned (World Values Survey 2009). However, the number of authoritarian country-years covered by these surveys is very limited.
} 
data on national energy production in ktonnes of oil equivalent and divided by real GDP. This gives energy production per unit of real gross domestic product (Energy production). Table 1 presents the correlation statistics for the variables used in the paper.

\section{Empirical Findings}

We first model air and water pollution in a country random effects model with a first-order autoregressive process to capture the within-country serial correlation of the data. While the random-effects in our model are conceptually analogous to the country-fixed effects usually employed in Time-Series-Cross-Sectional data (TSCS) analyses, they have certain statistical advantages. Unlike random effects models, fixed effects models use one degree of freedom for each unit. Such loss of information inflates the standard errors and makes the estimates of the coefficients less precise. This is important for our analysis because missing data (on RPC and Tax ratio, for example) already reduces the number of countries to 39-46 (time period 1980-2003). More importantly, the authoritarian regime type variables are often slow-moving or even time-invariant. It is well known that estimating country fixed effects with slowmoving and time-invariant variables is often problematic. ${ }^{21}$

The model can be written as $y_{i, t}=\beta_{0}+\beta_{i}+X \beta+\xi_{i, t}$, where $\beta_{0}$ is the population intercept, $\beta_{i}$ represents mean-zero random unit intercepts and is normally distributed. $\mathrm{X} \beta$ is the linear covariates and an estimate of their impact on the dependent variable. Residuals are further decomposed as $\xi_{i, t}=\rho \xi_{i, t-1}+\epsilon_{i, t}$, where $\rho$ is the first order autoregressive correlation term (AR1), and $\epsilon_{i, t}$ follows the normal distribution $N\left(0, \sigma^{2}\right)$. We also include year fixed effects to control for common exogenous shocks (e.g., sharp increases in international oil price) and region dummy variables to control any potential regional effects

\footnotetext{
${ }^{21}$ Even though recent literature has proposed statistical tools to deal with this, see for example, Plümper and Troeger 2007, there is still debate on whether the proposed estimators indeed solve the problem and about which estimator(s) outperform the others (Greene 2010; but also see Plümper and Troeger 2011).
} 
that might not be captured by the explanatory variables. ${ }^{22}$ We present the empirical findings in Table 2-4 with one table for each type of pollutant. We have two measures for state capacity here --- relative political capacity $(R P C)$ and Tax ratio (of GDP). Thus for each pollutant, we present two model specifications: each model specification includes basic social-economic control variables from GDP per capita to energy production, communist/socialist legacies, and region variables.

The results from $\mathrm{SO}_{2}$ regressions (Table 2) show that there is a positive association between state extractive capacity, either measured by $R P C$ or Tax ratio, and the logged level of $\mathrm{SO}_{2}$ per capita emission for authoritarian states. Not only is the association statistically significant across both model specifications, but also the magnitude of the association is substantively important. For instance, a coefficient of about 0.12 associated with the RPC measure suggests that on average, a one standard deviation upward shift in a country's relative political capacity, which is about 0.54 in our sample of observations, is expected to be associated with an increase in annual $\mathrm{SO}_{2}$ emissions of about 0.07 kilograms per-capita in logarithm. Note that the average of $\mathrm{SO}_{2}$ per capita emission in the sample is about 1.47 kilograms per-capita in logarithm.

Interestingly, we also find an important effect for authoritarian regime types. With military regime as the baseline regime type, single-party regimes are associated with higher levels of $\mathrm{SO}_{2}$ per capita emission. With coefficients of personalist regimes and monarchies not statistically different from that of the baseline military regimes, a coefficient around 0.8 associated with single-party regimes suggests that on a yearly basis, a single-party regime on average emits an additional 0.8 kilograms per-capita (in logarithm) of $\mathrm{SO}_{2}$ more than all other types of authoritarian regimes --- this is more than half of the average $\mathrm{SO}_{2}$ per capita emission level in the sample (again, the mean is about 1.47 kilograms per-capita in

\footnotetext{
${ }^{22}$ The region dummies are East Asia, Eastern Europe \& post-Soviet, Latin America, North Africa \& Middle East, South-East Asia, South Asia, and Sub-Saharan Africa.
} 
logarithm). ${ }^{23}$ Furthermore, GDP per capita and its square term are significantly associated with emission and the signs of coefficients indicate an inverted U-shaped environmental Kuznets curve: per capita SO2 emission goes up with wealth until reaching a threshold after which increasing wealth decreases emission. Finally, urban population and energy production are also positively associated with $\mathrm{SO}_{2}$ emission.

Insert Table 2-4 about here.

Table 3 presents the empirical findings for $\mathrm{CO}_{2}$ emission. In contrast to the case of $\mathrm{SO}_{2}$ emissions, here we do not find evidence for an inverted U-shaped environmental Kuznets curve, though the negative impacts of urban population and energy production are still statistically significant. In terms of the effects of regime types, the relationship between single-party regimes and emission is not significant. Moreover, similar to the case of $\mathrm{SO}_{2}$ emission, both RPC and Tax ratio increase $\mathrm{CO}_{2}$ emission significantly. In terms of the regional effects, with the baseline region being East Asia, we find that countries from South Asia emit significantly less $\mathrm{CO}_{2}$.

Slightly different from the findings of two major air pollutants, those from BOD regressions (table 4) suggest that few covariates in our model actually have any impact on this type of water pollution. Among all the control variables, we only find that GDP growth

${ }^{23}$ In terms of the potential explanations for the positive relationship between single-party regimes and $\mathrm{SO}_{2}$ emissions, we think this might be a function of the size of the key constituencies associated with authoritarian regimes. Among all four types of authoritarian regimes, single-party regimes are often associated with the largest size of key constituencies which mainly include the military and party members. For example, there are about 77.9 million (in 2009) members of the Chinese Communist Party, which is roughly $6 \%$ of the population; the Communist Party of Vietnam has 3.6 million members: roughly $4 \%$ of the population. Notoriously, the PRI in Mexico also included quite large groups of farmers and trade-unions in the movement. Larger key constituencies require more payoffs, often in the form of private goods, from the ruler assuming that she/he wants to stay in power and the best way to do so is to keep these constituencies happy. Higher level of private good provisions often implies a reduction in public goods which might also include the environmental type --this might cause the reduction in environmental qualities. 
reduces and urban population increases BOD per capita. We might simply need better quality data for BOD discharges: for the same time period and a similar set of countries, the available number of observations for the BOD regressions is almost one third lower than those in the $\mathrm{SO}_{2}$ and $\mathrm{CO}_{2}$ regressions. However, even with few observations, state extractive capacity measured as both RPC and Tax ratio is still positively associated with BOD pollution.

Insert Table 5 about here.

Our strongest finding is the positive effect of state capacity on pollution. In order to test whether this result is robust to other estimation strategies, we ran OLS regressions with lagged dependent variable and country and year fixed effects. Adding country fixed effects essentially makes our estimation rely exclusively on temporal variation in the data. A country's state capacity, at least for those two measures in our data, does not change much over time. Therefore, we think that a fixed effects model, by giving up cross-sectional variation of independent variables in explaining air and water pollution, is a stronger test for the state capacity argument. Moreover, we choose not to include regime type variables and the dummy variable for communist/socialist regime because they are almost time-invariant. The results from fixed effects models are reported in Table 5. Here, except for one out of the six model specifications --- using RPC for $\mathrm{SO}_{2}$, we find that both measures of state capacity are still positively associated with pollutions at reasonably high statistical significance levels. $^{24}$

Insert Figure 1 about here.

\footnotetext{
${ }^{24}$ Also note that in the case of $\mathrm{SO} 2$ and $\mathrm{CO} 2$, the sizes of estimated mean coefficients for state capacity variables in fixed effects models are smaller than those from random effects models. On the other hand, in the case of BOD, the estimated mean coefficients for state capacity variables are similar in size in random and fixed effects models. This seems to suggest that cross-sectional variation in the state capacity variables accounts much more for the variation in air pollution (SO2 and $\mathrm{CO} 2$ ) than that in water pollution (BOD).
} 
Finally, we have argued in the theoretical section that our model of environmental investment gap is specific to the context of authoritarian politics. Democratic politics would change the incentives of the ruler because democratic incumbents on average place more weight on maximizing social welfare rather than rent (Lake and Baum 2001). Moreover, they are more likely to be institutionally constrained by de facto opposition parties in the legislature whose policy preferences may diverge from the incumbents'. To empirically test our theoretical expectation, we add polity score and its interactive term with the state capacity variables to the fixed effects model specifications in Table 5. An interactive model is ideal to test the domain restriction of our theory: if our model only works for non-democracies, we should see the positive effect of state capacity on pollution indicators disappear in democracies. Figure 1 shows the conditional effects of polity score on the state capacity variables across pollution types with mean estimates and confidence intervals. ${ }^{25}$ Across all six sub-figures, we observe the same pattern that confirms our theoretical expectation. State capacity, measure either by relative political capacity (RPC) or tax ratio, is positively associated with pollution when polity score is at the low and/or medium level. ${ }^{26}$ The positive effects become smaller with increasing level of polity scores and eventually disappear (judging by the associated statistical significance indicated by the $95 \%$ confidence intervals) when polity score reaches around -3 for $\mathrm{SO} 2$ (Figure 1(b)), and around 3 for $\mathrm{CO} 2$ and BOD(Figure $1(\mathrm{c})$ to $(\mathrm{f}))^{27}$

\footnotetext{
${ }^{25}$ We have included an online appendix with more details on testing the domain restriction of our theory at authors' websites.

${ }^{26}$ This positive relationship is also statistically significant except when we use RPC for the case of SO2 (Figure 1(a)).

${ }^{27}$ Polity score is bounded between -10 and 10 with higher values indicating more democratic systems. The common cut-off point for democracies often used in previous studies is a polity score of 6 and that for autocracies -6 . The middle category is often referred to as anocracies.
} 


\section{Conclusion and Discussion on Future Research}

In this paper, we present a model of environmental politics in the authoritarian world. We show that it is typically the case that the larger the state's capacity, the worse its environmental quality: while both infrastructural investment and environmental protection increase with higher state capacity, the former increases at a faster rate, which enlarges the environmental investment gap. Our theoretical model predicts that greater state capacity should be associated with bad environmental outcomes in the authoritarian regimes. We test our theory for three types of major air and water pollutants $\left(\mathrm{SO}_{2}, \mathrm{CO}_{2}\right.$, and $\left.\mathrm{BOD}\right)$. We find that state capacity is associated with higher levels of all three types of pollutants in authoritarian states.

The findings presented in this paper contribute to the literature on environmental politics and to a broader literature on the politics of development in numerous ways. First, some studies that address the debate on the impact of democracy on environmental pollution $^{28}$ find that democracies with greater state capacity are associated with higher environmental quality (Janicke 1997; Ehrhardt-Martinez 2002). The central result in this paper, however, suggests that unlike democracies, greater state capacity in autocracies generates a larger environmental investment gap that leads to more environmental degradation. This result at least partially challenges the conventional belief that higher state capacity in developing countries - where authoritarian regimes exist - promotes effective implementation of optimal policies (e.g. "better" environmental policies) that enhances social welfare (Herbst 2000; Van de Walle 2001). Indeed, our study shows that the effect of state capacity on especially environmental outcomes critically depends on the institutional context, specifically the type of political regime in place.

\footnotetext{
${ }^{28}$ See e.g., Li and Reuveny 2006, Scruggs 2009, Bernauer and Koubi 2009.
} 
Second, recent research provides valuable insights on how the impact of authoritarian regimes on outcomes as diverse as economic growth and the propensity for dictators to resort to conflict (e.g., Gandhi 2008; Wright 2008; Weeks 2011). Yet extant studies on autocracies have paid less attention toward systematically theorizing the effect of autocratic states on a substantively important outcome: environmental quality. The results presented in this paper take a critical step forward with respect to understanding how and when the quality of the environment can deteriorate in authoritarian regimes. As such, our main finding may provide a useful foundation for future research on the link between autocracies and environmental quality. Third, recall that a key assumption in our model is that the authoritarian ruler seeks to maximize his discounted rent. Notwithstanding this assumption, an additional claim that emerges from our model is that leaders in authoritarian states will invest in infrastructure even when they seek to maximize their expected rent. This claim calls into question extant theoretical arguments which posit that autocrats as "roving bandits" often fail to adequately provide public-goods such as infrastructure investment primarily because they are more focused on being predatory by extracting rent (e.g., McGuire and Olson 1995). It may be worthwhile to assess whether our supplementary theoretical claim mentioned above is empirically valid.

The results reported in this paper also provide two main policy predictions. First, our model predicts that environmental problems will get worse as a function of state capacity as long as infrastructural public goods investment is more productive of surplus than investment in environmental regulation. If there came a point where environmental regulation mattered more, the relationship reverses, though. This may shed some light on recent developments in China where the five year plan for the period 2011 to 2015 has a strong environmental focus (BBC News, 3rd March 2011) and Premier Wen Jiabao announced a reduction in target 
growth rates from $7.5 \%$ to $7 \%$ partly to address environmental concerns (BBC News, $28^{\text {th }}$ February 2011).

There is no doubt that China faces enormous environmental challenges (World Bank 2001), partly due to its very rapid economic development over the last two decades. Some believe that poor environmental quality and resource shortages will increasingly constrain China's economic growth, while increasing environmental protest will generate strains for the regime (Economy 2004; Grumbine 2007). It may be that China is on the cusp at which its considerable state capacity will turn to an advantage from the environmental point of view, reducing the environmental investment gap if it grows. Second, if the quality of the environment declines further in authoritarian regimes with greater state capacity, then leaders of such states may become more sensitized toward the long-term negative externalities of environmental degradation. If so, then we may potentially observe such autocratic leaders to be more receptive toward international policy initiatives that seek to curtail environmental pollution via multilateral cooperation between states at the systemic level.

There are many assumptions in our model that require further investigation. Not all authoritarian regimes can be plausibly characterized as pure rent-seekers (Wintrobe 1990). If a leader was purely concerned to maximize his chances of retaining tenure, increasing state capacity might be associated with worse environmental quality, but for different reasons to the ones we suggest. If the leader had to pay some attention to all members of the selectorate by paying them off with private goods, and if this necessitated building state capacity through time, we would expect greater pressure on the profits of enterprises in the private sector, damaging their ability to invest in cleaner technology. We might also expect direct environmental effects due to a bias towards current consumption and further attempts to suppress dissent among the general population, including environmental dissent. 
Although there is certainly evidence from large scale social surveys and from other sources for environmental concern in authoritarian systems (World Values Survey 2009), it is plausible that the degree of concern varies. If authoritarian leaders have to pay attention to dissent both within the selectorate and (to some extent) among the wider citizenry, environmental demand should matter to their behavior, too, if they have the capacity to meet it. This suggests an interaction between demand and state capacity. As it is the case that a variety of causal mechanisms could explain our empirical results, detailed empirical work will be required to tell which are the most plausible. ${ }^{29}$ Lastly, we also found that single-party authoritarian states are positively associated with $\mathrm{SO}_{2}$ emissions. It is beyond the scope of this paper to study in more detail the link between authoritarian regime-types and environmental pollution. But researchers may gain valuable insights by evaluating how different authoritarian institutions may influence environmental quality.

\footnotetext{
${ }^{29}$ A more direct test of our causal story is look at the correlations between state capacity and regimes types on the one hand, and government spending patterns across different types of public goods on the other hand. More specifically, the differences between government spending on economic affairs (e.g., on mining, mineral resources, manufacturing and construction) and the environment can be operationalized as the environmental investment gap variable. However, data on government environmental spending (e.g., from IMF's Government Financial Statistics) are often missing, especially for developing countries and for the pre-1990s period.
} 


\section{References:}

Ambec, Stefan, and Paul Lanoie. 2008. Does It Pay to Be Green? A Systematic Overview Academy of Management Perspectives 22(4): 45-62.

Arbetman-Rabinowitz, Marina and Kristin Johnson. 2007. Relative Political Capacity: Theoretical and Empirical Underpinnings. Mimeo.

Barret, Scott and Kathryn Graddy. 2000. Freedom, Growth and the Environment. Environment and Development Economics 5(4): 433-456.

Battaglini, Marco. and Stephen Coate. 2008.A Dynamic Theory of Public Spending, Taxation and Debt. American Economic Review, 98(1): 201-236.

Bernauer, Thomas, and Vally Koubi. 2009. Effects of Political Institutions on Air Quality. Ecological Economics 68 (5): 1355-65.

Bernhagen P. 2008. Business and international environmental agreements: domestic sources of participation and compliance by advanced industrialized democracies. Global Environmental Politics 8:78-110.

Besley, Timothy and Torsten Persson. 2010. State Capacity, Conflict, and Development. Econometrica 78(1): 1-34.

Broz and Maliniak. 2011. Malapportionment, Gasoline Taxes, and Climate Change. Working paper.

Bueno de Mesquita Bruce, Alastair Smith, Randolph M. Siverson, and James D. Morrow. 2003. The Logic of Political Survival. Cambridge: MIT Press.

Campbell, John L. 1993. The state and fiscal sociology. Annual Review of Sociology 19: $163-185$.

Cao, Xun, and Aseem Prakash. 2012. Trade Competition and Environmental Regulations: Domestic Political Constraints and Issue Visibility. Journal of Politics 74(1): 66-82. 
Chang, Eric, and Miriam A. Golden. 2010. Sources of Corruption in Authoritarian Regimes. Social Science Quarterly 91(1): 1-20.

Cheibub, Jose Antonio. 1998. Political regimes and the extractive capacity of governments: Taxation in democracies and dictatorships. World Politics 50(3): 349-376.

Cheibub, José Antonio, and Jennifer Gandhi. 2004. Classifying political regimes: a six-fold measure of democracies and dictatorships. Prepared for the annual meeting of the American Political Science Association, Chicago, September 2004.

Cheibub, José Antonio, Jennifer Gandhi, and James R. Vreeland. 2010. Democracy and Dictatorship Revisited. Public Choice 143 (1-2): 67-101.

Clarke, Kevin A., and Randall Stone. 2008. Democracy and the Logic of Political Survival. American Political Science Review 102(3): 387-392.

Congleton, Roger D. 1992. Political Institutions and Pollution Control. Review of Economics and Statistics 74:412-421.

de Soysa, Indra, and Eric Neumayer. 2005. False Prophet or Genuine Savior? International Organization 59(3):731-72.

Doyle and Simpson. 2006. Traversing more than speed bumps: Green politics under authoritarian regimes in Burma and Iran. Environmental Politics 15(5): 750-767.

Dryzek, J. S. 1987. Rational Ecology: Environment and Political Economy. Oxford: Blackwell.

Economy, Elizabeth C. 2004. The River Runs Black: The Environmental Challenge to China's Future. Princeton N.J.: Princeton University Press.

Esfahani, H. and M. Ramirez. 2003. Institutions, Infrastructure, and Economic Growth. Journal of Development Economics 70: 443-447.

Ericson, Richard E. 1991. The Classical Soviet-Type Economy: Nature of the System and Implications for Reform. Journal of Economic Perspectives 5(4), 11-27. 
Ehrhardt-Martinez, Karen; Crenshaw, Edward, and J. Craig Jenkins . 2002. Deforestation and the environmental Kuznets curve: a cross national investigation of intervening mechanisms". Social Science Quarterly 83 (1): 226-243.

Esty, Daniel and Michael Porter. 2005. National Environmental Performance: an Empirical Analysis of Policy Results and Determinants. Environment and Development Economics 10(3): 391-434.

Fredriksson and Millimet. 2004. Comparative politics and environmental taxation. Journal of Environmental Economics and Management 48(4): 705-722.

Fredriksson and Wollscheid. 2007. Democratic Institutions versus Autocratic Regimes: The Case of Environmental Policy. Public Choice 130(3/4): 381-393.

Gallagher, Mary, and Jonathan Hanson. 2009. Power Tool or Dull Blade? Resilient Autocracy and the Selectorate Theory. Unpublished manuscript.

Gandhi, Jennifer. 2008. Political institutions under dictatorship. New York: Cambridge University Press.

Gandhi, Jennifer, and Adam Przeworski. 2006. Cooperation, cooptation, and rebellion under dictatorships. Economics and Politics, 18(1): 1-26.

Geddes, Barbara. 1999. Authoritarian Breakdown: Empirical Test of a Game-Theoretic Argument, paper prepared for presentation at the annual meeting of the American Political Science Association, Atlanta, September 1999.

Geddes, Barbara. 2006. Stages of Development in Authoritarian Regimes. In World Order after Leninism, ed. VladimirTismaneanu, Marc M.Howard, and RudraSil. Seattle, WA : University of Washington Press, 149-70.

Greene, William. 2010. Fixed Effects Vector Decomposition: A Magical Solution to the Problem of Time Invariant Variables in Fixed Effects Models? Working paper. 
Grumbine, R. Edward. 2007. China's Emergence and the Prospects for Global Sustainability, Bioscience57(3): 249-255.

Gulbrandsen LH, Andresen S. 2004. NGO influence in the implementation of the Kyoto protocol: compliance, flexibility mechanisms, and sinks. Global Environmental Politics $4: 54-75$.

Hanson, Jonathan. 2007. Political Institutions, Social Heterogeneity, and Development Outcomes. Paper presented at the annual meeting of the Midwest Political Science Association, Palmer House Hilton, Chicago, Illinois, April 12, 2007.

Hendrix, Cullen S. 2010. Measuring state capacity: Theoretical and empirical implications for the study of civil conflict. Journal of Peace Research 47: 273-285.

Herbst, Jeffrey. 2000. States and Power in Africa: Lessons in Authority and Control. Princeton University Press.

Hicks, Robert L., Bradley C. Parks, J. Timmons Roberts and Michael J. Tierney. 2008. Greening Aid? Understanding the Environmental Impact of Development Assistance, Oxford University Press.

Hill, Marquita K. 2004. Understanding Environmental Pollution 2nd Edition. Cambridge, Cambridge University Press.

Janicke, M. 1997. The political system's capacity for environmental policy. In M. Janicke and H. Weidner (Eds.), National environmental policies. New York: Springer, pp.1-24. Knack, Stephen. 2005. Review of the Logic of Political Survival. Journal of Economic Literature 43(4): 1068-1070.

Kvaløy, Berir, Henning Finseraas and Ola Listhaug (2012) The publics' concern for global warming: A cross-national study of 47 countries. Journal of Peace Research 49(1): $11-22$. 
Lai, Brian, and Dan Slater. 2006. Institutions of the Offensive: Domestic Sources of Dispute Initiation in Authoritarian Regimes, 1950-1992. American Journal of Political Science 50 (1): 113-126.

Lake, David and Baum, Matthew. 2001. The Invisible Hand of Democracy: Political Control and the Provision of Public Services. Comparative Political Studies. 34(6):587-621.

Li, Quan and Rafael Reuveny. 2006. Democracy and Environmental Degradation. International Studies Quarterly 2006 50: 935-956.

McGuire, Martin C., and Mancur Olson. 1996. The economics of autocracy and majority rule. Journal of Economic Literature 34:72-96.

Midlarsky, Manus. 1998. Democracy and the Environment: An Empirical Assessment. Journal of Peace Research 35:341-361.

Marshall, Monty G., Ted Robert Gurr, and Keith Jaggers. 2010. Polity IV Project: Political Regime Characteristics and Transitions, 1800-2009 Dataset Users' Manual, mimeo. Morrison, Kevin M. 2010. Oil, Nontax Revenue, and the Redistributional Foundations of Regime Stability. International Organization 63: 107-38.

Mumme, Stephen, Richard Bath, and Valerie J. Assetto. 1988. Political Development and Environmental Policy in Mexico. Latin American Research Review 23: 7-34.

O'Donnell G, Schmitter P. 1986. Transitions from Authoritarian Rule: Tentative Conclusions about Uncertain Democracies. Baltimore: Johns Hopkins University Press. 81pp.

Oldfield, Jonathan D. 2005. Russian Nature: Exploring the Environmental Consequences of Societal Change, Aldershot, Ashgate.

Organski, A. F. K. and Jacek Kugler. 1980. The War Ledger. Chicago, University of Chicago Press. 
O'Rourke, Dara and Sarah Connolly. 2003. Just Oil: The Distribution of Environmental and Social Impacts of Oil Production and Consumption. Annual Review of Environment and Resources 28:587-617.

Østby, Gudrun. 2008. Polarization, Horizontal Inequalities and Violent Civil Conflict. Journal of Peace Research 45(2): 143-162.

Peceny, Mark, and , Christopher K. Butler. 2004. The Conflict Behavior of Authoritarian Regimes. International Politics 41 (4): 565-581.

Pickering, Jeffrey, and Emizet F. Kisangani. 2010. Diversionary Despots? Comparing Autocracies' Propensities to Use and to Benefit from Military Force. American Journal of Political Science 54 (2): 477-493.

Plümper, Thomas and Vera E. Troeger. 2007. Efficient estimation of time-invariant and rarely changing variables in finite sample panel Analyses with unit effects, Political Analysis 15: 124-139.

Plümper, Thomas and Vera E. Troeger. 2011. Fixed Effects Vector Decomposition: Response, working paper. http://ssrn.com/abstract=1737480.

Porter, M., and Van der Linde, C. 1995. Toward a new conception of the environmentcompetitiveness relationship. Journal of Economic Perspective, 9(4), 97-118.

Pryde, Phillip R. 1991. Environmental Management in the Soviet Union. Cambridge, Cambridge University Press.

Regan, Patrick M. and Daniel Norton. 2005. Greed, Grievance, and Mobilization: The Onset of Protest, Rebellion, and Civil War. Journal of Conflict Resolution 49(3): 1-18.

Repetto, Robert, Dale Rothman, Paul Faeth, and Duncan Austin. 1996. Has environmental protection really reduced productivity growth? We need unbiased measures. World Resources Institute. 
Scruggs, Lyle. 2009. "Democracy and Environmental Protection: An Empirical Analysis." Working paper, University of Connecticut.

Simmons, Beth. 2010. Treaty Compliance and Violation. Annual Review of Political Science 13: $273-296$.

Singer, J. David, Stuart Bremer, and John Stuckey. (1972). "Capability Distribution, Uncertainty, and Major Power War, 1820-1965." in Bruce Russett (ed) Peace, War, and Numbers, Beverly Hills: Sage, 19-48.

Sprinz, Detlef F., Michael Aklin, Doris Fuchs, and Richard Meyer-Eppler (2009) 'Does Politics Influence Carbon Emissions?', Paper Prepared for Presentation at the 50th Annual Convention of the International Studies Association, 15-18 February 2009, New York Marriott Marquis, New York, NY.

Stern, David I. 2005. Global sulfur emissions from 1850 to 2000. Chemosphere 58: 163-175.

Svolik, Milan. 2008. Authoritarian reversals and democratic consolidation. American Political Science Review 102(2): 153-168.

Thies, Cameron G. 2005. War, rivalry, and state building in Latin America. American Journal of Political Science 49(3): 451-465.

Thies, Cameron G. 2010. Of rulers, rebels, and revenue: State capacity, civil war onset, and Primary Commodities. Journal of Peace Research 47(3): 321-332.

Tilly, Charles. 1975. Reflections on the History of European State-Making, Pp. 3-83 in The Formation of Nation States in Western Europe, edited by Charles Tilly. Princeton, N.J.: Princeton University Press.

Tilly, Charles. 1990. Coercion, Capital, and European States, A.D.990-1990. Cambridge: Blackwell.

Van de Walle, Nicolas. 2001. African Economies and the Politics of Permanent Crisis, 1979-1999. New York: Cambridge University Press. 
Walder, Andrew G. 2009. Political Sociology and Social Movements. Annual Review of Sociology 35: 393-412.

Ward, Hugh and Cao, Xun. 2012. Domestic and International Influences on Green Taxation. Comparative Political Studies volume 45(9): 1075-1103.

Weeks, Jessica. 2011. Strongmen and Straw Men: Authoritarian Regimes and the Initiation of International Conflict. Working paper.

Wintrobe, Ronald. 1990. The Tinpot and the Totalitarian: An Economic Theory of Dictatorship. American Political Science Review 84(3): 849-872.

World Bank. 2001. China, Air, Land and Water: Environmental Priorities for a New Millenium. Washington D. C. : World Bank.

World Bank. 2008. World Development Indicators. Available at: http://data.worldbank.org/data-catalog. Accessed 11 February 2008.

World Bank. 2012. Global Economic Prospects: Uncertainties and Vulnerabilities. Washington, DC: World Bank.

World Values Survey. 2009. World Values Survey, 1981-2008, Official Aggregate v.20090901. World Values Survey Association. Aggregate File Producer: ASEP/JDS, Madrid. Accessed November, 2009.

Wright, Joseph. 2008. Do Authoritarian Institutions Constrain? How Legislatures Affect Economic Growth and Investment. American Journal of Political Science 52 (2): 322343.

Wright, Joseph. 2009. How Foreign Aid Can Foster Democratization in Authoritarian Regimes. American Journal of Political Science 53 (3): 552-571.

Wright, Joseph, and Matthew Winters. 2010. The Politics of Effective Foreign Aid. Annual Review of Political Science 13: 61-80. 


\section{Appendix A: Derivation of Conditions in Formal Model}

Proof of Lemma 1: Assuming that constraints C1-C5 are slack, by complementary slackness Lagrange multipliers associated with these constraints are zero, and the Lagrangian for the ruler's program is $\mathrm{R}_{\Sigma}$. Notice that because of the Cobb-Douglas surplus production function, $\mathrm{R}_{\Sigma}$ is strictly concave in $\mathrm{I}_{t}, \mathrm{E}_{\mathrm{t}}$ and $\mathrm{C}_{\mathrm{t}}$, so first-order conditions are sufficient for an optimum. Notice that any optimal solution must have $\mathrm{i}_{\mathrm{T}}=\mathrm{e}_{\mathrm{T}}=\mathrm{c}_{\mathrm{T}}=0$ : because investment only affect surplus after a lag, to plan to invest at time T has no value for the ruler because his term must have finished once the T-th period is over.

First we derive the value of partial derivative of surplus in period $t+1$ with respect to investments in period $t$ that must hold in an optimum. The proof will be by backward induction from period $\mathrm{T}$. For brevity we derive the condition for $\mathrm{i}_{\mathrm{t}}$, but analogous derivations apply for $e_{t}$ and $c_{t}$. For an optimum

$$
\delta \mathrm{R}_{\Sigma} / \delta \mathrm{i}_{\mathrm{T}-1}=0=\Pi_{\mathrm{T}} \varphi^{\mathrm{T}} \delta \mathrm{Y}_{\mathrm{T}} / \delta \mathrm{i}_{\mathrm{T}-1}-\Pi_{\mathrm{T}-1} \varphi^{\mathrm{T}-1} \mathrm{p}_{\mathrm{I}}
$$

Noting that $\Pi_{\mathrm{T}-1}>0$ (because $\Pi_{0}=1$ and $\left.\pi_{\mathrm{t}}>0\right)$ and $\varphi^{\mathrm{T}-1}>0($ as $\varphi>0)$ we can simplify the right hand side by dividing through by these terms and recall that $\Pi_{\mathrm{T}}=\Pi_{\mathrm{T}-1} \pi_{\mathrm{T}-1}$ to get:

$$
\delta \mathrm{Y}_{\mathrm{T}} / \delta \mathrm{i}_{\mathrm{T}-1}=\mathrm{p}_{\mathrm{I}} / \varphi \pi_{\mathrm{T}-1}
$$

Now for $0 \leq \mathrm{t}^{\prime}<\mathrm{t}^{\prime \prime} \leq \mathrm{T}$

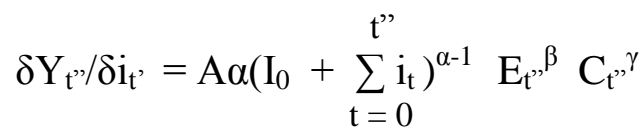

So, in particular, for $0 \leq \mathrm{t}<\mathrm{T}-1$

$$
\delta \mathrm{Y}_{\mathrm{T}} / \delta \mathrm{i}_{\mathrm{t}}=\delta \mathrm{Y}_{\mathrm{T}} / \delta \mathrm{i}_{\mathrm{T}-1}=\mathrm{p}_{\mathrm{I}} / \varphi \pi_{\mathrm{T}-1}
$$

Moving backward in time for an optimum

$$
\delta \mathrm{R}_{\Sigma} / \delta \mathrm{i}_{\mathrm{T}-2}=0=\Pi_{\mathrm{T}-1} \varphi^{\mathrm{T}-1} \delta \mathrm{Y}_{\mathrm{T}-1} / \delta \mathrm{i}_{\mathrm{T}-2}+\Pi_{\mathrm{T}} \varphi^{\mathrm{T}} \delta \mathrm{Y}_{\mathrm{t}} / \delta \mathrm{i}_{\mathrm{T}-2}-\Pi_{\mathrm{T}-2} \varphi^{\mathrm{T}-2} \mathrm{p}_{\mathrm{I}}
$$

Substituting for $\delta \mathrm{Y}_{\mathrm{t}} / \delta \mathrm{i}_{\mathrm{T}-2}$ and simplifying

$$
0=\pi_{\mathrm{T}-2} \varphi \delta \mathrm{Y}_{\mathrm{T}-1} / \delta \mathrm{i}_{\mathrm{T}-2}+\left(\left(\pi_{\mathrm{T}-2} \pi_{\mathrm{T}-1} \varphi^{2} \mathrm{p}_{\mathrm{I}}\right) / \varphi \pi_{\mathrm{T}-1}\right)-\mathrm{p}_{\mathrm{I}} \text { or }
$$




$$
\delta \mathrm{Y}_{\mathrm{T}-1} / \delta \mathrm{i}_{\mathrm{T}-2}=\mathrm{p}_{\mathrm{I}}\left(1-\varphi \pi_{\mathrm{T}-2}\right) / \varphi \pi_{\mathrm{T}-2}
$$

Now if we can show that $\delta \mathrm{Y}_{\mathrm{t} "+1} / \delta \mathrm{i}_{\mathrm{t}} "=\quad=\mathrm{p}_{\mathrm{I}}\left(1-\varphi \pi_{\mathrm{t}^{\prime}}\right) / \varphi \pi_{\mathrm{t}}$ " for all $\mathrm{t}^{\prime \prime}$ such that $\mathrm{t}^{\prime}+1 \leq \mathrm{t}$ " $\leq \mathrm{T}-2$ implies that

$$
\delta \mathrm{Y}_{\mathrm{t}^{\prime}+1} / \delta \mathrm{i}_{\mathrm{t}^{\prime}}=\mathrm{p}_{\mathrm{I}}\left(1-\varphi \pi_{\mathrm{t}^{\prime}}\right) / \varphi \pi_{\mathrm{t}^{\prime}}
$$

then we can conclude by backwards induction that for $0 \leq \mathrm{t}<\mathrm{T}-2$

$$
\delta \mathrm{Y}_{\mathrm{t}+1} / \delta \mathrm{i}_{\mathrm{t}}=\mathrm{p}_{\mathrm{I}}\left(1-\varphi \pi_{\mathrm{t}}\right) / \varphi \pi_{\mathrm{t}}
$$

for we have already shown that this is true for $\mathrm{t}=\mathrm{T}-2$. We have

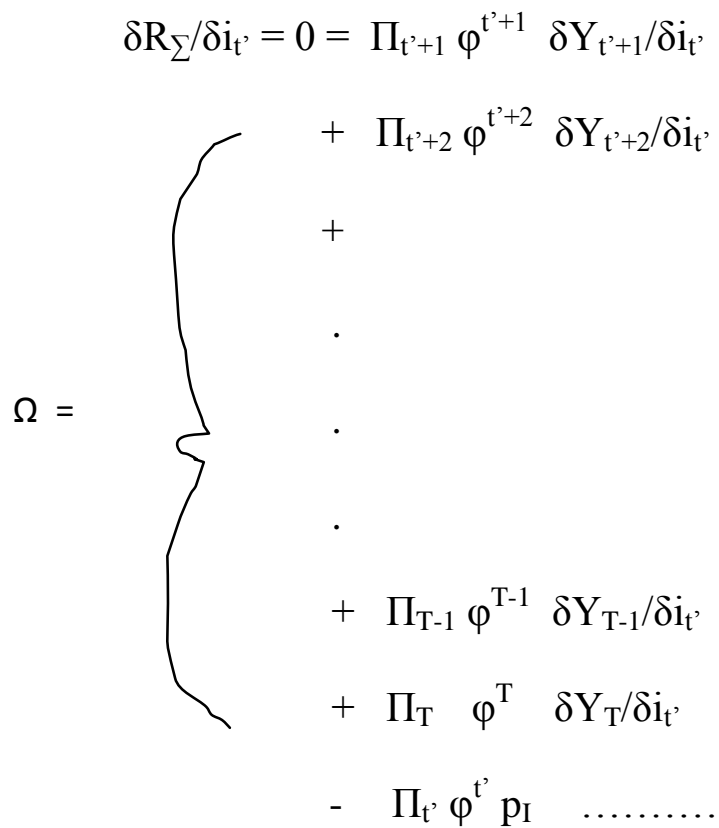

It will be convenient to refer to the sum of the inner terms in expression 2 as $\Omega$. Noting that by expression $1 \delta \mathrm{Y}_{\mathrm{T}} / \delta \mathrm{i}_{\mathrm{t}^{\prime}}=\delta \mathrm{Y}_{\mathrm{T}} / \delta \mathrm{i}_{\mathrm{T}-1}$ and $\delta \mathrm{Y}_{\mathrm{T}-1} / \delta \mathrm{i}_{\mathrm{t}^{\prime}}=\delta \mathrm{Y}_{\mathrm{T}-1} / \delta \mathrm{i}_{\mathrm{T}-2}$ and substituting, the last two terms in $\Omega$ sum to

$$
p_{\mathrm{I}}\left(\left(\varphi^{\mathrm{T}-1} \Pi_{\mathrm{T}-1}\left(1-\varphi \pi_{\mathrm{T}-2}\right) / \varphi \pi_{\mathrm{T}-2}\right)+\varphi^{\mathrm{T}} \Pi_{\mathrm{T}} / \varphi \pi_{\mathrm{T}-1}\right)
$$

$=$

$$
p_{I}\left(\varphi^{\mathrm{T}-2} \Pi_{\mathrm{T}-2}-\varphi^{\mathrm{T}-1} \Pi_{\mathrm{T}-1}+\varphi^{\mathrm{T}-1} \Pi_{\mathrm{T}-1}\right)
$$

$=$

$$
p_{\mathrm{I}} \varphi^{\mathrm{T}-2} \Pi_{\mathrm{T}-2}
$$

Proceeding in a similar manner the sum of the last three terms in $\Omega$ is 


$$
\begin{aligned}
& p_{\mathrm{I}}\left(\left(\varphi^{\mathrm{T}-2} \Pi_{\mathrm{T}-2}\left(1-\varphi \pi_{\mathrm{T}-3}\right) / \varphi \pi_{\mathrm{T}-3}\right)+\varphi^{\mathrm{T}-2} \Pi_{\mathrm{T}-2}\right) \text { or } \\
& \mathrm{p}_{\mathrm{I}} \varphi^{\mathrm{T}-3} \Pi_{\mathrm{T}-3}
\end{aligned}
$$

and more generally the sum of term $t^{*}$ and above in $\Omega$ is

$$
\begin{aligned}
& p_{\text {I }}\left(\left(\varphi^{t^{*}} \Pi_{t^{*}}\left(1-\varphi \pi_{t^{*}}\right) / \varphi \pi_{t^{*}}\right)+\varphi^{t^{*}} \Pi_{t^{*}}\right) \text { or } \\
& \text { p }_{\text {I }} \varphi^{t^{*}-1} \Pi_{t^{*}-1}
\end{aligned}
$$

So

$$
\begin{aligned}
& \delta \mathrm{R}_{\Sigma} / \delta \mathrm{i}_{\mathrm{t}^{\prime}}=0=\Pi_{\mathrm{t}^{\prime}+1} \varphi^{\mathrm{t}^{\prime}+1} \delta \mathrm{Y}_{\mathrm{t}^{\prime}+1} / \delta \mathrm{i}_{\mathrm{t}^{\prime}}+\mathrm{p}_{\mathrm{I}} \varphi^{\mathrm{t}^{*}-1} \Pi_{\mathrm{t}^{*}-1}-\mathrm{p}_{\mathrm{I}} \varphi^{\mathrm{t}^{\prime}} \Pi_{\mathrm{t}} \text { or } \\
& \varphi \pi_{\mathrm{t}^{\prime}} \delta \mathrm{Y}_{\mathrm{t}^{\prime}+1} / \delta \mathrm{i}_{\mathrm{t}^{\prime}}+\mathrm{p}_{\mathrm{I}} \varphi \pi_{\mathrm{t}^{\prime}}=\mathrm{p}_{\mathrm{I}} \text { or } \\
& \delta \mathrm{Y}_{\mathrm{t}^{\prime}+1} / \delta \mathrm{i}_{\mathrm{t}^{\prime}}=\mathrm{p}_{\mathrm{I}}\left(1-\varphi \pi_{\mathrm{t}^{\prime}}\right) / \varphi \pi_{\mathrm{t}^{\prime}}
\end{aligned}
$$

Summarizing we have shown that: i) $\delta \mathrm{Y}_{\mathrm{T}-1} / \delta \mathrm{i}_{\mathrm{T}-2}=\mathrm{p}_{\mathrm{I}}\left(1-\varphi \pi_{\mathrm{T}-2}\right) / \varphi \pi_{\mathrm{T}-2}$; and if for all $\mathrm{t}$ " such that $\mathrm{t}^{\prime}+1 \leq \mathrm{t}^{\prime \prime} \leq \mathrm{T}-2, \delta \mathrm{Y}_{\mathrm{t}^{\prime \prime}+1} / \delta \mathrm{i}_{\mathrm{t}} "=\mathrm{p}_{\mathrm{I}}\left(1-\varphi \pi_{\mathrm{t}^{\prime}}\right) / \varphi \pi_{\mathrm{t}}$, then it follows that;

ii) $\delta \mathrm{Y}_{\mathrm{t}^{\prime}+1} / \delta \mathrm{i}_{\mathrm{t}^{\prime}}=\mathrm{p}_{\mathrm{I}}\left(1-\varphi \pi_{\mathrm{t}^{\prime}}\right) / \varphi \pi_{\mathrm{t}^{\prime}}$. We conclude by backward induction that for $0 \leq \mathrm{t} \leq \mathrm{T}-2$ $\delta \mathrm{Y}_{\mathrm{t}+1} / \delta \mathrm{i}_{\mathrm{t}}=\mathrm{p}_{\mathrm{I}}\left(1-\varphi \pi_{\mathrm{t}}\right) / \varphi \pi_{\mathrm{t}}$. Using analogous arguments we can show that $\delta \mathrm{Y}_{\mathrm{T}} / \delta \mathrm{e}_{\mathrm{T}-1}=\mathrm{p}_{\mathrm{E}} /$ $\varphi \pi_{\mathrm{T}-1}$ and $\delta \mathrm{Y}_{\mathrm{T}} / \delta \mathrm{c}_{\mathrm{T}-1}=\mathrm{p}_{\mathrm{C}} / \varphi \pi_{\mathrm{T}-1}$, while for $0 \leq \mathrm{t} \leq \mathrm{T}-2$

$\delta \mathrm{Y}_{\mathrm{t}+1} / \delta \mathrm{e}_{\mathrm{t}}=\mathrm{p}_{\mathrm{E}}\left(1-\varphi \pi_{\mathrm{t}}\right) / \varphi \pi_{\mathrm{t}}$ and

$\delta \mathrm{Y}_{\mathrm{t}+1} / \delta \mathrm{c}_{\mathrm{t}}=\mathrm{p}_{\mathrm{C}}\left(1-\varphi \pi_{\mathrm{t}}\right) / \varphi \pi_{\mathrm{t}}$

Thus for $0 \leq \mathrm{t} \leq \mathrm{T}-1$ the ratios of the partial derivatives of surplus in the next period with respect to investments is equal to the ratio of the price of the investments. Specifically

$$
\begin{aligned}
& \frac{\delta \mathrm{Y}_{\mathrm{t}+1} / \delta \mathrm{i}_{\mathrm{t}}}{\delta \mathrm{Y}_{\mathrm{t}+1} / \delta \mathrm{e}_{\mathrm{t}}}=\frac{\mathrm{p}_{\mathrm{I}}}{\mathrm{p}_{\mathrm{E}}}=\frac{\alpha\left(\mathrm{E}_{\mathrm{t}}+\mathrm{e}_{\mathrm{t}}\right)}{\beta\left(\mathrm{I}_{\mathrm{t}}+\mathrm{i}_{\mathrm{t}}\right)} \frac{\alpha \mathrm{E}_{\mathrm{t}+1},}{\beta \mathrm{I}_{\mathrm{t}+1}}, \\
& \frac{\delta \mathrm{Y}_{\mathrm{t}+1} / \delta \mathrm{i}_{\mathrm{t}}}{\delta \mathrm{Y}_{\mathrm{t}+1} / \delta \mathrm{c}_{\mathrm{t}}}=\frac{\mathrm{p}_{\mathrm{I}}}{\mathrm{p}_{\mathrm{C}}}=\frac{\alpha\left(\mathrm{C}_{\mathrm{t}}+\mathrm{c}_{\mathrm{t}}\right)}{\gamma\left(\mathrm{I}_{\mathrm{t}}+\mathrm{i}_{\mathrm{t}}\right)} \frac{\alpha \mathrm{C}_{\mathrm{t}+1},}{\gamma \mathrm{I}_{\mathrm{t}+1}}, \\
& \frac{\delta \mathrm{Y}_{\mathrm{t}+1} / \delta \mathrm{e}_{\mathrm{t}}}{\delta \mathrm{Y}_{\mathrm{t}+1} / \delta \mathrm{c}_{\mathrm{t}}}=\frac{\mathrm{p}_{\mathrm{E}}}{\mathrm{p}_{\mathrm{C}}}=\frac{\beta\left(\mathrm{C}_{\mathrm{t}}+\mathrm{c}_{\mathrm{t}}\right)}{\gamma\left(\mathrm{E}_{\mathrm{t}}+\mathrm{e}_{\mathrm{t}}\right)}=\frac{\beta \mathrm{C}_{\mathrm{t}+1}}{\gamma \mathrm{E}_{\mathrm{t}+1}},
\end{aligned}
$$


Suppose that the ruler's total investment in infrastructure, environment and state capacity is $\mathrm{k}_{\mathrm{t}}$, so that $\mathrm{p}_{\mathrm{I}} \mathrm{i}_{\mathrm{t}}+\mathrm{p}_{\mathrm{E}} \mathrm{e}_{\mathrm{t}}+\mathrm{p}_{\mathrm{C}} \mathrm{c}_{\mathrm{t}}=\mathrm{k}_{\mathrm{t}}$ or

$\mathrm{p}_{\mathrm{I}}\left(\mathrm{I}_{\mathrm{t}+1}{ }^{\prime}-\mathrm{I}_{\mathrm{t}}\right)+\mathrm{p}_{\mathrm{E}}\left(\mathrm{E}_{\mathrm{t}+1}{ }^{\prime}-\mathrm{E}_{\mathrm{t}}\right)+\mathrm{p}_{\mathrm{C}}\left(\mathrm{C}_{\mathrm{t}+1}{ }^{\prime}-\mathrm{C}_{\mathrm{t}}\right)=\mathrm{k}_{\mathrm{t}}$

Then solving (1) through (4) simultaneously,

$$
\begin{aligned}
\mathrm{I}_{\mathrm{t}+1}{ }^{\prime}= & \frac{\alpha\left(\mathrm{k}_{\mathrm{t}}+\mathrm{p}_{\mathrm{I}} \mathrm{I}_{\mathrm{t}}+\mathrm{p}_{\mathrm{E}} \mathrm{E}_{\mathrm{t}}+\mathrm{p}_{\mathrm{C}} \mathrm{C}_{\mathrm{t}}\right)}{\mathrm{p}_{\mathrm{I}}(\alpha+\beta+\gamma)} \\
\mathrm{E}_{\mathrm{t}+1}{ }^{\prime}= & \frac{\beta\left(\mathrm{k}_{\mathrm{t}}+\mathrm{p}_{\mathrm{I}} \mathrm{I}_{\mathrm{t}}+\mathrm{p}_{\mathrm{E}} \mathrm{E}_{\mathrm{t}}+\mathrm{p}_{\mathrm{C}} \mathrm{C}_{\mathrm{t}}\right)}{\mathrm{p}_{\mathrm{E}}(\alpha+\beta+\gamma)} \\
\mathrm{C}_{\mathrm{t}+1}{ }^{\prime}= & \frac{\gamma\left(\mathrm{k}_{\mathrm{t}}+\mathrm{p}_{\mathrm{I}} \mathrm{I}_{\mathrm{t}}+\mathrm{p}_{\mathrm{E}} \mathrm{E}_{\mathrm{t}}+\mathrm{p}_{\mathrm{C}} \mathrm{C}_{\mathrm{t}}\right)}{\mathrm{p}_{\mathrm{C}}(\alpha+\beta+\gamma)}
\end{aligned}
$$

And as $\mathrm{D}_{\mathrm{t}+1}=\left(\mathrm{I}_{\mathrm{t}+1}{ }^{\prime}-\mathrm{E}_{\mathrm{t}+1}{ }^{\prime}\right)$

$$
D_{t+1}=\frac{\left(\alpha p_{E}-\beta p_{I}\right)\left(k_{t}+p_{I} I_{t}+p_{E} E_{t}+p_{C} C_{t}\right)}{p_{I} p_{E}(\alpha+\beta+\gamma)}
$$

Proof of Proposition 1: From the expression in (7), we obtain

$$
\delta \mathrm{D}_{\mathrm{t}+1} / \delta \mathrm{C}_{\mathrm{t}}=\mathrm{p}_{\mathrm{C}}\left(\alpha \mathrm{p}_{\mathrm{E}}-\beta \mathrm{p}_{\mathrm{I}}\right) / \mathrm{p}_{\mathrm{I}} \mathrm{p}_{\mathrm{E}}(\alpha+\beta+\gamma)
$$

So the environmental investment gap at time $\mathrm{t}+1$ increases with state capacity at time $\mathrm{t}$ so long as $\left(\alpha p_{E}-\beta p_{I}\right)>0$, as asserted in the text. Moreover as

$$
\delta \varepsilon_{\mathrm{t}+1} / \delta \mathrm{C}_{\mathrm{t}}=\delta \varepsilon_{\mathrm{t}+1} / \delta \mathrm{D}_{\mathrm{t}+1} * \delta \mathrm{D}_{\mathrm{t}+1} / \delta \mathrm{C}_{\mathrm{t}}
$$

Environmental quality at time $t+1$ falls with state capacity at time t so long as $\left(\alpha p_{E}-\beta p_{I}\right)>0$.

Proof of claim 1: From the solution for $\mathrm{I}_{\mathrm{t}+1}$ ' in Lemma 1, we find that

$$
\delta \mathrm{I}_{\mathrm{t}+1}, / \delta \mathrm{C}_{\mathrm{t}}=\alpha \mathrm{p}_{\mathrm{C}} / \mathrm{p}_{\mathrm{I}}(\alpha+\beta+\gamma)>0
$$

Likewise, from the solution for $\mathrm{E}_{\mathrm{t}+1}$ ' in Lemma 1, we obtain

$$
\delta \mathrm{E}_{\mathrm{t}+1}, / \delta \mathrm{C}_{\mathrm{t}}=\beta \mathrm{p}_{\mathrm{C}} / \mathrm{p}_{\mathrm{E}}(\alpha+\beta+\gamma)>0
$$


Figure 1: Testing the effects of state capacity, conditional on regime types (polity): In all figures, the long-dashed lines are the upper and lower bounds of the 95\% confidence intervals of the estimated effect; the dark line in between the dashed lines represents the mean coefficient estimated. The distributions of the polity scores variable are displayed by their histograms, in gray color, with frequencies shown by the vertical axis on right-hand side of each figure.

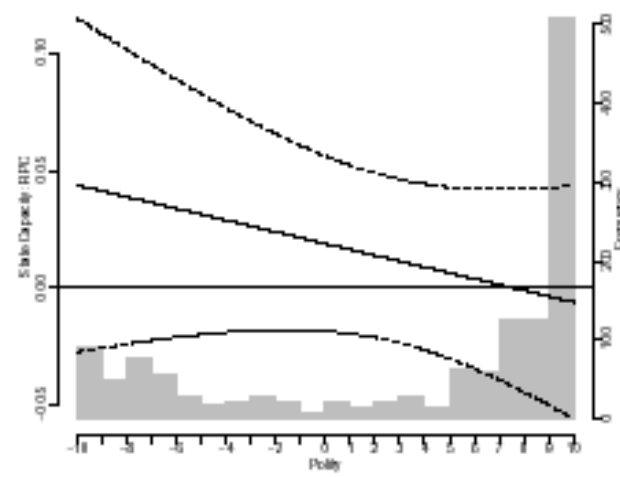

(a) $\mathrm{SO} 2: \mathrm{RPC}$

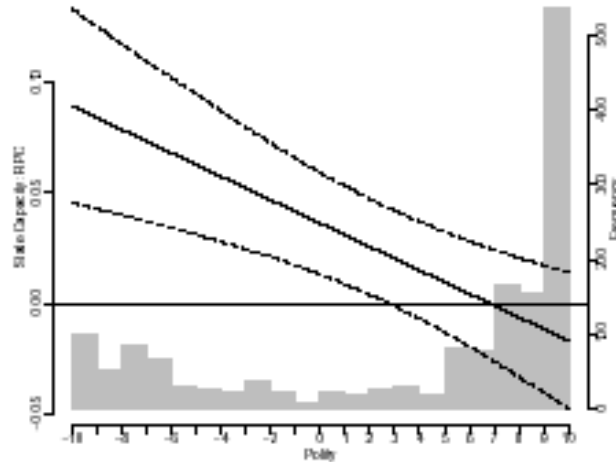

(c) $\mathrm{CO} 2 \mathrm{RPC}$

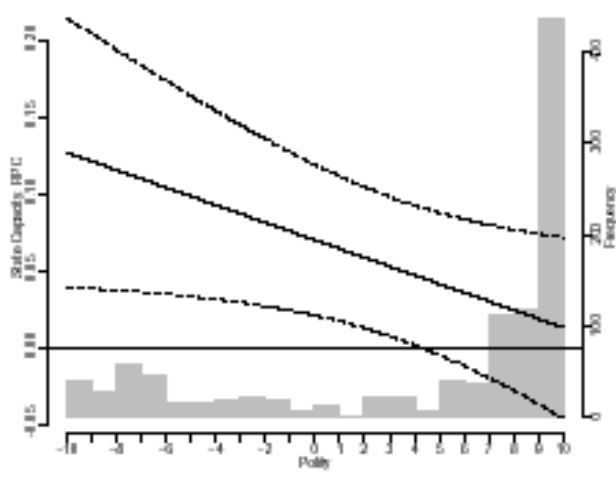

(e) BOD: RPC

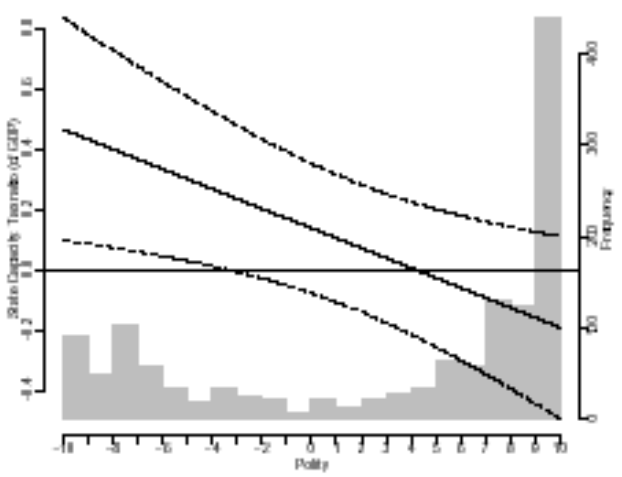

(b) SO2: tax ratio

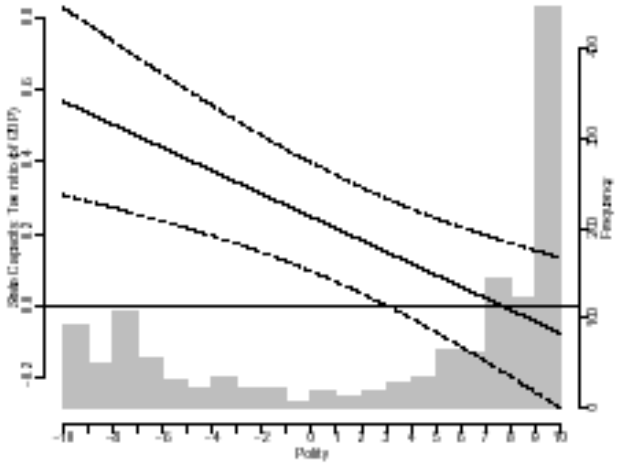

(d) $\mathrm{CO} 2$ : tax ratio

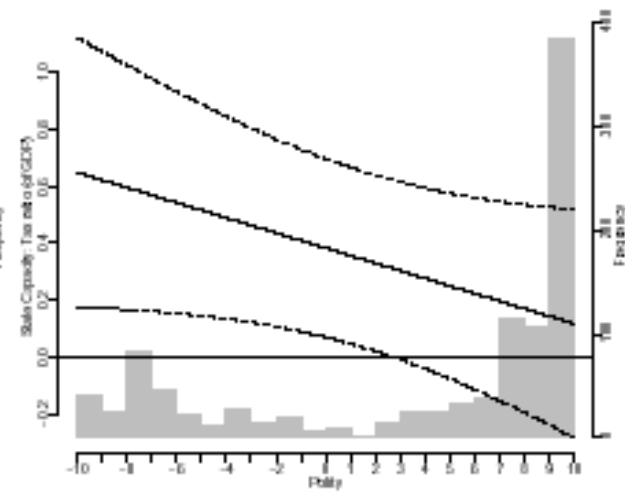

(f) BOD: tax ratio 
Table 1: Correlation among covariates

\begin{tabular}{|c|c|c|c|c|c|c|c|c|c|c|c|c|c|c|c|}
\hline & 1 & 2 & 3 & 4 & 5 & 6 & 7 & 8 & 9 & 10 & 11 & 12 & 13 & 14 & 15 \\
\hline$\overline{1: \mathrm{RPC}}$ & 1.00 & 0.91 & -0.14 & 0.23 & 0.06 & 0.05 & 0.17 & -0.09 & 0.10 & -0.04 & -0.07 & 0.07 & 0.12 & 0.12 & -0.13 \\
\hline 2: Tax ratio & 0.91 & 1.00 & -0.15 & 0.25 & -0.09 & -0.04 & 0.11 & 0.05 & 0.35 & -0.04 & 0.04 & 0.19 & 0.31 & 0.30 & 0.05 \\
\hline 3: Personalist & -0.14 & -0.15 & 1.00 & -0.57 & -0.26 & -0.31 & -0.23 & -0.29 & -0.25 & -0.11 & -0.09 & -0.19 & -0.09 & -0.15 & -0.13 \\
\hline 4: Single party & 0.23 & 0.25 & -0.57 & 1.00 & -0.29 & -0.34 & 0.43 & -0.07 & 0.01 & 0.04 & 0.15 & -0.02 & 0.05 & -0.14 & -0.21 \\
\hline 5: Military & -0.06 & -0.09 & -0.26 & -0.29 & 1.00 & -0.16 & -0.13 & -0.05 & -0.04 & 0.02 & -0.02 & 0.02 & -0.24 & -0.06 & -0.07 \\
\hline 6: Mona & -0.05 & -0.04 & -0.31 & -0.34 & -0.16 & 1.00 & -0.16 & 0.51 & 0.36 & 0.08 & -0.07 & 0.26 & 0.30 & 0.41 & 0.48 \\
\hline $\begin{array}{l}\text { 7: Socialist/Communist } \\
\text { legacies }\end{array}$ & 0.17 & 0.11 & -0.23 & 0.43 & -0.13 & -0.16 & 1.00 & -0.09 & 0.11 & 0.02 & -0.03 & -0.03 & -0.03 & -0.04 & -0.03 \\
\hline 8: GDP per capita & -0.09 & 0.05 & -0.29 & -0.07 & -0.05 & 0.51 & -0.09 & 1.00 & 0.55 & 0.03 & 0.29 & 0.66 & 0.25 & 0.32 & 0.50 \\
\hline 9: Inc & 0.10 & 0.35 & -0.25 & 0.01 & -0.04 & 0.36 & 0.11 & 0.55 & 0 & 0.06 & 33 & 0.58 & 0.42 & 0.59 & 0.61 \\
\hline 10: GDF & -0.04 & -0.04 & -0.11 & 0.04 & 0.02 & 0.08 & 0.02 & 0.03 & 0.06 & 1.00 & 0.07 & -0.00 & 0.05 & 0.06 & 0.04 \\
\hline 11: $\mathrm{Pc}$ & -0.07 & 0.04 & -0.09 & 0.15 & -0.02 & -0.07 & -0.03 & 0.29 & 0.03 & 0.07 & 1.00 & 0.31 & -0.12 & -0.03 & -0.14 \\
\hline $\begin{array}{l}\text { 12: Urban population (\% } \\
\text { pop.) }\end{array}$ & 0.07 & 0.19 & -0.19 & -0.02 & 0.02 & 0.26 & -0.03 & 0.66 & 0.58 & -0.00 & 0.31 & 1.00 & 0.26 & 0.37 & 0.23 \\
\hline 13: $\mathrm{Tr}$ & 0.12 & 0.31 & -0.09 & 0.05 & -0.24 & 0.30 & -0.03 & 0.25 & 0.42 & 0.05 & -0.12 & 0.26 & 1.00 & 0.21 & 0.32 \\
\hline 14: $\mathrm{Fu}$ & 0.12 & 0.30 & -0.15 & -0.14 & -0.06 & 0.41 & -0.04 & 0.32 & 0.59 & 0.06 & -0.03 & 0.37 & 0.21 & 1.00 & 0.73 \\
\hline $\begin{array}{l}\text { 15: Energy production ( } \% \\
\text { GDP) }\end{array}$ & -0.13 & 0.05 & -0.13 & -0.21 & -0.07 & 0.48 & -0.03 & 0.50 & 0.61 & 0.04 & -0.14 & 0.23 & 0.32 & 0.73 & 1.00 \\
\hline
\end{tabular}


Table 2: Models on SO2 per capita emission: using RPC and tax ratio for state capacity.

\begin{tabular}{|c|c|c|c|c|c|c|}
\hline & \multicolumn{3}{|c|}{ Model 1} & \multicolumn{3}{|c|}{ Model 2} \\
\hline & Coef. & $\hat{\sigma}$ & $\mathrm{p}(>|\mathrm{t}|)$ & Coef. & $\hat{\sigma}$ & $\mathrm{p}(>|\mathrm{t}|)$ \\
\hline (Intercept) & -9.5823 & 3.193 & 0.003 & -8.1188 & 3.040 & 0.008 \\
\hline GDP per capita & 2.3114 & 0.686 & 0.001 & 1.7325 & 0.684 & 0.012 \\
\hline GDP per capita 2 & -0.1223 & 0.040 & 0.002 & -0.0893 & 0.040 & 0.028 \\
\hline Industry (\% of GDP) & 0.0012 & 0.004 & 0.723 & 0.0004 & 0.004 & 0.917 \\
\hline GDP growth rate & -0.0003 & 0.002 & 0.847 & -0.0008 & 0.002 & 0.607 \\
\hline Population density & -0.0318 & 0.135 & 0.814 & 0.1529 & 0.136 & 0.262 \\
\hline Urban population (\% pop.) & 0.0207 & 0.008 & 0.011 & 0.0249 & 0.008 & 0.002 \\
\hline Trade openness & 0.0351 & 0.073 & 0.632 & 0.0318 & 0.076 & 0.678 \\
\hline Fuel export (\% of exp) & -0.0147 & 0.008 & 0.054 & -0.0111 & 0.009 & 0.211 \\
\hline Energy production (\% GDP) & 0.1459 & 0.090 & 0.106 & 0.1886 & 0.092 & 0.041 \\
\hline Socialist/Communist legacies & -0.6193 & 0.793 & 0.441 & 0.0958 & 0.178 & 0.591 \\
\hline \multicolumn{7}{|l|}{ Regime (baseline: Military): } \\
\hline Personalist & $\begin{array}{l}0.1931 \\
0.0766\end{array}$ & $\begin{array}{l}0.503 \\
0.409\end{array}$ & $\begin{array}{l}0.109 \\
0.853\end{array}$ & $\begin{array}{l}0.0291 \\
0.1182\end{array}$ & $\begin{array}{l}0.470 \\
0.366\end{array}$ & $\begin{array}{l}0.189 \\
0.749\end{array}$ \\
\hline Single party & 0.8359 & 0.386 & 0.039 & 0.8711 & 0.336 & 0.014 \\
\hline $\begin{array}{r}\text { State Capacity: } \\
\text { RPC }\end{array}$ & 0.1194 & 0.044 & 0.007 & & & \\
\hline Tax ratio (of GDP) & & & & 0.7060 & 0.275 & 0.011 \\
\hline \multicolumn{7}{|l|}{ Region (baseline: East Asia): } \\
\hline Latin America & -0.6884 & 0.852 & 0.426 & -0.3647 & 0.662 & 0.585 \\
\hline North Africa \& Middle East & -0.6831 & 0.864 & 0.435 & -0.3173 & 0.632 & 0.619 \\
\hline South-East Asia & -0.6096 & 0.871 & 0.490 & -0.5023 & 0.638 & 0.437 \\
\hline South Asia & -1.7929 & 1.256 & 0.164 & -1.2588 & 0.791 & 0.120 \\
\hline Sub-Saharan Africa & -0.5898 & 0.912 & 0.523 & -0.4048 & 0.603 & 0.506 \\
\hline AR1: & & & 0.971 & & & 0.969 \\
\hline $\operatorname{StdDev}_{\left(\text {Intercept }_{i}\right)}$ & & & 0.0002 & & & 0.0003 \\
\hline StdDev(Residual) & & & 0.731 & & & 0.725 \\
\hline $\mathrm{N}$ of countries & & & 39 & & & 46 \\
\hline $\mathrm{N}$ of Observations & & & 370 & & & 390 \\
\hline Year fixed effects & & & 1980-2001 & & & 1980-1999 \\
\hline
\end{tabular}

Year fixed effects are estimated for all models but not reported because of space limit. 
Table 3: Models on CO2 per capita emission: using RPC and tax ratio for state capacity.

\begin{tabular}{|c|c|c|c|c|c|c|}
\hline & \multicolumn{3}{|c|}{ Model 3} & \multicolumn{3}{|c|}{ Model 4} \\
\hline & Coef. & $\hat{\sigma}$ & $\mathrm{p}(>|\mathrm{t}|)$ & Coef. & $\hat{\sigma}$ & $\mathrm{p}(>|\mathrm{t}|)$ \\
\hline (Intercept) & -4.3460 & 2.492 & 0.082 & -1.9656 & 2.155 & 0.363 \\
\hline GDP per capita & 0.3748 & 0.515 & 0.467 & -0.0828 & 0.471 & 0.861 \\
\hline GDP per capita ${ }^{2}$ & 0.0175 & 0.029 & 0.554 & 0.0337 & 0.028 & 0.237 \\
\hline Industry ( $\%$ of GDP) & -0.0016 & 0.003 & 0.574 & -0.0021 & 0.003 & 0.523 \\
\hline GDP growth rate & -0.0017 & 0.002 & 0.293 & 0.0002 & 0.002 & 0.899 \\
\hline Population density & 0.0353 & 0.124 & 0.777 & 0.0627 & 0.124 & 0.614 \\
\hline Urban population (\% pop.) & 0.0082 & 0.005 & 0.106 & 0.0179 & 0.005 & 0.001 \\
\hline Trade openness & 0.0579 & 0.051 & 0.254 & 0.0569 & 0.055 & 0.304 \\
\hline Fuel export (\% of exp) & 0.0042 & 0.007 & 0.517 & 0.0081 & 0.007 & 0.279 \\
\hline Energy production (\% GDP) & 0.1830 & 0.082 & 0.027 & 0.2206 & 0.082 & 0.008 \\
\hline Socialist/Communist legacies & -0.8809 & 0.772 & 0.263 & 0.0405 & 0.167 & 0.809 \\
\hline \multicolumn{7}{|l|}{ Regime (baseline: Military): } \\
\hline Personalist & $\begin{array}{l}0.3145 \\
-0.3390\end{array}$ & $\begin{array}{l}0.54 / \\
0.410\end{array}$ & $\begin{array}{l}0.509 \\
0.415\end{array}$ & $\begin{array}{l}-0.0003 \\
-0.1503\end{array}$ & $\begin{array}{l}0.450 \\
0.356\end{array}$ & $\begin{array}{l}0.805 \\
0.675\end{array}$ \\
\hline Single party & 0.1958 & 0.385 & 0.615 & 0.2137 & 0.331 & 0.522 \\
\hline $\begin{array}{r}\text { State Capacity: } \\
\text { RPC }\end{array}$ & 0.1299 & 0.036 & 0.000 & & & \\
\hline Tax ratio (of GDP) & & & & 0.7367 & 0.224 & 0.001 \\
\hline \multicolumn{7}{|l|}{ Region (baseline: East Asia): } \\
\hline Latin America & -0.8429 & 0.841 & 0.324 & -1.1387 & 0.634 & 0.081 \\
\hline North Africa \& Middle East & -0.3564 & 0.858 & 0.681 & -0.3467 & 0.616 & 0.577 \\
\hline South-East Asia & -0.3679 & 0.868 & 0.675 & -0.6300 & 0.633 & 0.326 \\
\hline South Asia & -2.5810 & 1.187 & 0.038 & -2.2210 & 0.761 & 0.006 \\
\hline Sub-Saharan Africa & -1.0789 & 0.890 & 0.235 & -1.4963 & 0.591 & 0.016 \\
\hline AR1: & & & 0.414 & & & 0.349 \\
\hline $\operatorname{StdDev}_{\left(\text {Intercept }_{i}\right)}$ & & & 0.696 & & & 0.668 \\
\hline StdDev(Residual) & & & 0.173 & & & 0.170 \\
\hline $\mathrm{N}$ of countries & & & 39 & & & 46 \\
\hline $\mathrm{N}$ of Observations & & & 422 & & & 390 \\
\hline Year fixed effects & & & 1980-2003 & & & 1980-1999 \\
\hline
\end{tabular}

Note: Year fixed effects are estimated for all models; not reported because of space limit. 
Table 4: Models on BOD per capita emission: using RPC and tax ratio for state capacity.

\begin{tabular}{|c|c|c|c|c|c|c|}
\hline & \multicolumn{3}{|c|}{ Model 5} & \multicolumn{3}{|c|}{ Model 6} \\
\hline & Coef. & $\hat{\sigma}$ & $\mathrm{p}(>|\mathrm{t}|)$ & Coef. & $\hat{\sigma}$ & $\mathrm{p}(>|\mathrm{t}|)$ \\
\hline (Intercept) & -5.6892 & 3.969 & 0.153 & -2.7238 & 3.802 & 0.474 \\
\hline GDP per capita & -0.4822 & 0.900 & 0.593 & -1.1398 & 0.880 & 0.196 \\
\hline GDP per capita ${ }^{2}$ & 0.0518 & 0.054 & 0.336 & 0.0902 & 0.053 & 0.093 \\
\hline Industry (\% of GDP) & -0.0065 & 0.005 & 0.219 & -0.0088 & 0.006 & 0.156 \\
\hline GDP growth rate & -0.0054 & 0.003 & 0.035 & -0.0065 & 0.003 & 0.020 \\
\hline Population density & 0.0609 & 0.134 & 0.649 & 0.1553 & 0.139 & 0.266 \\
\hline Urban population (\% pop.) & 0.0199 & 0.009 & 0.022 & 0.0185 & 0.008 & 0.030 \\
\hline Trade openness & -0.0508 & 0.114 & 0.657 & -0.0346 & 0.116 & 0.765 \\
\hline Fuel export (\% of exp) & -0.0046 & 0.015 & 0.765 & -0.0009 & 0.018 & 0.959 \\
\hline Energy production (\% GDP) & -0.0865 & 0.156 & 0.579 & -0.2120 & 0.157 & 0.179 \\
\hline Socialist/Communist legacies & -1.3459 & 0.792 & 0.100 & 0.0521 & 0.240 & 0.828 \\
\hline Regime (baseline: Military): & & & & & & \\
\hline Monarchy & -0.9937 & 0.541 & 0.077 & -0.7696 & 0.458 & 0.102 \\
\hline Personalist & -0.6383 & 0.388 & 0.111 & -0.6370 & 0.350 & 0.078 \\
\hline Single party & -0.2321 & 0.369 & 0.534 & -0.1083 & 0.322 & 0.739 \\
\hline $\begin{array}{r}\text { State Capacity: } \\
\text { RPC }\end{array}$ & 0.1396 & 0.067 & 0.039 & & & \\
\hline Tax ratio (of GDP) & & & & 0.7596 & 0.434 & 0.082 \\
\hline $\begin{array}{r}\text { Region (baseline: East } \\
\text { Asia): }\end{array}$ & & & & & & \\
\hline East Europe \& post-Soviet & & & & 0.3859 & 0.620 & 0.538 \\
\hline Latin America & -0.5239 & 0.800 & 0.518 & -0.8466 & 0.642 & 0.197 \\
\hline North Africa \& Middle East & -0.4746 & 0.810 & 0.563 & -0.9369 & 0.602 & 0.129 \\
\hline South-East Asia & 0.4594 & 0.808 & 0.574 & -0.0768 & 0.596 & 0.898 \\
\hline South Asia & 1.0031 & 1.213 & 0.415 & -0.4098 & 0.742 & 0.584 \\
\hline Sub-Saharan Africa & -0.3502 & 0.867 & 0.689 & -1.0370 & 0.570 & 0.078 \\
\hline AR1: & & & 0.917 & & & 0.856 \\
\hline $\operatorname{StdDev}_{\left(\text {Intercept }_{i}\right)}$ & & & 0.358 & & & 0.492 \\
\hline StdDev(Residual) & & & 0.597 & & & 0.472 \\
\hline $\mathrm{N}$ of countries & & & 39 & & & 43 \\
\hline $\mathrm{N}$ of Observations & & & 302 & & & 300 \\
\hline Year fixed effects & & & $1980-2003$ & & & 1980-1999 \\
\hline
\end{tabular}

Note: Year fixed effects are estimated for all models; not reported because of space limit. 
Table 5: OLS with lagged dependent variable and country and year fixed effects: using RPC and tax ratio as state capacity.

\begin{tabular}{|c|c|c|c|c|c|c|c|c|c|c|c|c|c|c|c|c|c|c|}
\hline & \multicolumn{6}{|c|}{ "SO2 per capita } & \multicolumn{6}{|c|}{ "CO2 per capita } & \multicolumn{6}{|c|}{ "BOD per capita } \\
\hline & Coef. & $\hat{\sigma}$ & $\mathrm{p}(>|\mathrm{t}|)$ & Coef. & $\hat{\sigma}$ & $\mathrm{p}(>|\mathrm{t}|)$ & Coef. & $\hat{\sigma}$ & $\mathrm{p}(>|\mathrm{t}|)$ & Coef. & $\hat{\sigma}$ & $\mathrm{p}(>|\mathrm{t}|)$ & Coef. & $\hat{\sigma}$ & $\mathrm{p}(>|\mathrm{t}|)$ & Coef. & $\hat{\sigma}$ & $\mathrm{p}(>|\mathrm{t}|)$ \\
\hline (Intercept) & -0.903 & 2.558 & 0.724 & 0.400 & 1.983 & 0.840 & -1.771 & 1.988 & 0.373 & -0.370 & 1.781 & 0.835 & 2.071 & 7.320 & 0.777 & 2.862 & 4.739 & 0.546 \\
\hline Lagged DV & 0.778 & 0.039 & 0.000 & 0.730 & 0.042 & 0.000 & 0.393 & 0.047 & 0.000 & 0.312 & 0.052 & 0.000 & 0.726 & 0.045 & 0.000 & 0.638 & 0.059 & 0.000 \\
\hline GDP per capita & 0.069 & 0.588 & 0.906 & -0.216 & 0.445 & 0.627 & -0.342 & 0.450 & 0.447 & -0.368 & 0.397 & 0.354 & -1.655 & 1.651 & 0.317 & -1.839 & 1.090 & 0.093 \\
\hline GDP per capita ${ }^{2}$ & -0.001 & 0.033 & 0.968 & 0.016 & 0.027 & 0.542 & 0.044 & 0.025 & 0.080 & 0.044 & 0.024 & 0.066 & 0.118 & 0.095 & 0.216 & 0.129 & 0.069 & 0.063 \\
\hline $\begin{array}{r}\text { Industry (\% of } \\
\text { GDP) }\end{array}$ & -0.000 & 0.002 & 0.989 & -0.002 & 0.003 & 0.440 & -0.000 & 0.002 & 0.671 & -0.002 & 0.002 & 0.360 & -0.007 & 0.005 & 0.198 & -0.013 & 0.007 & 0.071 \\
\hline GDP growth rate & -0.000 & 0.001 & 0.888 & 0.000 & 0.001 & 0.931 & 0.000 & 0.001 & 0.822 & 0.001 & 0.001 & 0.395 & -0.000 & 0.003 & 0.948 & -0.001 & 0.003 & 0.633 \\
\hline Population density & 0.266 & 0.225 & 0.236 & 0.285 & 0.246 & 0.247 & 0.234 & 0.167 & 0.161 & 0.226 & 0.219 & 0.301 & 0.371 & 0.479 & 0.439 & 0.258 & 0.503 & 0.608 \\
\hline $\begin{array}{r}\text { Urban population } \\
(\% \text { pop. })\end{array}$ & 0.007 & 0.005 & 0.132 & 0.003 & 0.005 & 0.587 & 0.002 & 0.003 & 0.607 & 0.006 & 0.005 & 0.219 & 0.016 & 0.010 & 0.100 & 0.026 & 0.012 & 0.041 \\
\hline Trade openness & 0.037 & 0.047 & 0.437 & 0.041 & 0.048 & 0.392 & 0.034 & 0.038 & 0.376 & 0.028 & 0.043 & 0.504 & -0.035 & 0.108 & 0.744 & -0.008 & 0.107 & 0.934 \\
\hline $\begin{array}{r}\text { Fuel export (\% of } \\
\text { exp) }\end{array}$ & -0.009 & 0.006 & 0.152 & -0.012 & 0.006 & 0.077 & 0.000 & 0.005 & 0.867 & 0.002 & 0.006 & 0.729 & -0.024 & 0.018 & 0.189 & -0.017 & 0.019 & 0.352 \\
\hline $\begin{array}{r}\text { Energy production } \\
(\% \text { GDP }) \\
\end{array}$ & -0.047 & 0.085 & 0.582 & -0.023 & 0.087 & 0.793 & 0.162 & 0.069 & 0.019 & 0.174 & 0.075 & 0.022 & -0.040 & 0.217 & 0.853 & -0.183 & 0.256 & 0.475 \\
\hline $\begin{array}{r}\text { State Capacity: } \\
\text { RPC } \\
\text { Tax ratio (of GDP) }\end{array}$ & 0.045 & 0.034 & 0.181 & 0.378 & 0.209 & 0.072 & 0.088 & 0.028 & 0.002 & 0.527 & 0.187 & 0.005 & 0.130 & 0.068 & 0.061 & 0.776 & 0.461 & 0.094 \\
\hline $\begin{array}{r}\mathrm{N} \text { of countries } \\
\mathrm{N} \text { of Observations } \\
\text { Ad. R-squared } \\
\text { Year fixed effects }\end{array}$ & & & $\begin{array}{c}39 \\
368 \\
0.979 \\
1980-01\end{array}$ & & & $\begin{array}{c}46 \\
389 \\
0.980 \\
1980-99\end{array}$ & & & $\begin{array}{c}39 \\
420 \\
0.991 \\
1980-03\end{array}$ & & & $\begin{array}{c}46 \\
389 \\
0.989 \\
1980-99\end{array}$ & & & \begin{tabular}{|c|}
33 \\
259 \\
0.935 \\
$1981-03$
\end{tabular} & & & $\begin{array}{c}38 \\
265 \\
0.943 \\
1981-99\end{array}$ \\
\hline
\end{tabular}

Note: Year and country fixed effects are estimated for all models but not reported because of space limit. 